\title{
Review Article \\ Salivary and Urinary Total Antioxidant Capacity as Biomarkers of Oxidative Stress in Humans
}

\author{
Ilaria Peluso and Anna Raguzzini \\ Center of Nutrition, Council for Agricultural Research and Economics (CREA-NUT), Via Ardeatina 546, 00178 Rome, Italy
}

Correspondence should be addressed to Ilaria Peluso; i.peluso@tiscali.it

Received 31 October 2015; Accepted 10 January 2016

Academic Editor: Runjan Chetty

Copyright ( 2016 I. Peluso and A. Raguzzini. This is an open access article distributed under the Creative Commons Attribution License, which permits unrestricted use, distribution, and reproduction in any medium, provided the original work is properly cited.

\begin{abstract}
Total Antioxidant Capacity (TAC) is a biomarker often used in order to investigate oxidative stress in many pathological conditions. Saliva and urine can be collected noninvasively and represent attractive diagnostic fluids for detecting biomarkers of various pathological conditions. The reviewed case-control and intervention studies that measured salivary or urinary TAC revealed that diseases, antioxidant foods, or supplements and age, gender, and lifestyle factors influenced salivary or urinary TAC. Salivary and urinary TAC were particularly affected by oral or renal status, respectively, as well as by infection; therefore these factors must be taken into account in both case-control and intervention studies. Furthermore, some considerations on sample collection and normalization strategies could be made. In particular, unstimulated saliva could be the better approach to measure salivary TAC, whereas $24 \mathrm{~h}$ or spontaneous urine collection should be chosen on the basis of the study outcome and of the creatinine clearance. Finally, the uric acid-independent TAC could be the better approach to evaluate red-ox status of body, in particular after nutritional interventions and in diseases associated with hyperuricaemia.
\end{abstract}

\section{Introduction}

Oxidative stress, defined as the imbalance between Reactive Oxygen Species (ROS) production and antioxidant defense inside human organism, is a risk factor playing a significant pathogenetic role for noncommunicable diseases [1]. A nonphysiological ROS production originates either by xenobiotics or by endogenous sources [2], such as the respiratory burst [3]. Synergistic interactions between antioxidants, in part involving antioxidant regeneration, must be taken into account in order to properly assess antioxidant status in vivo. Total Antioxidant Capacity (TAC), defined as the moles of oxidants neutralized by one litre of solution, is a biomarker measuring the antioxidant potential of body fluids [4]. Several reviews described the various assays commonly used for the measurement of TAC [5-8] and a good correlation between the results obtained with different methods was found $[9,10]$. Salivary and urinary collections are simple and noninvasive and this is the reason why TAC of saliva or urine has led to increasing interest. It has been suggested that saliva could constitute a first line of defense against free radicalmediated oxidative stress [11], whereas the composition of urine reflects the continuously changing environment of the body, which is affected, among other factors, by diet and in particular by polyphenol metabolites excreted in urine [12].

We aimed to review case-control and intervention studies that measured salivary [13-138] or urinary [138-179] TAC.

\section{Infection and Oral and Renal Status}

Saliva and urine are particularly affected by oral or renal status, respectively, as well as by infection; therefore the relationships of salivary and urinary TAC with these conditions have been investigated in many studies (Table 1). Urinary TAC increased during urinary tract infection [148, 149], while decreased levels of salivary TAC were observed during H. pylori $[130]$ and HIV [98, 112] infections and after a single consumption of enterococci containing Bryndza cheese [63]. The latter temporally affected the composition of oral microbiota [63].

On the contrary, dental caries, one of the most common infectious diseases worldwide, was associated with higher salivary TAC (Table 1). Therefore, the relationship between 
TABLE 1: Infection and oral and renal status.

\begin{tabular}{|c|c|c|c|c|}
\hline References & $\begin{array}{l}\text { Case-control } \\
\text { studies }\end{array}$ & $\begin{array}{l}\text { Salivary TAC } \\
\text { percentage }\left(n^{\circ}\right)\end{array}$ & $\begin{array}{c}\text { Urinary TAC } \\
\text { percentage }\left(n^{\circ}\right)\end{array}$ & $\begin{array}{l}\text { Treatment effect } \\
\text { percentage }\left(n^{\circ}\right)\end{array}$ \\
\hline $\begin{array}{l}98,112,130,148, \\
149]\end{array}$ & Infection & $\downarrow 100 \%(3 / 3)$ & $\uparrow(100 \%, 2 / 2)$ & $\begin{array}{l}\text { Salivary TAC } \\
\quad \uparrow \text { HAART in HIV+ }\end{array}$ \\
\hline $\begin{array}{l}16,45,47,60,61, \\
64,72,73,75,78, \\
84,90,99,103,104, \\
122,124,125]\end{array}$ & Caries & $\begin{array}{c}\uparrow 81.2 \%(13 / 16) \\
\leftrightarrow 6.3 \%(1 / 16) \\
\downarrow 12.5 \%(2 / 16)\end{array}$ & & $\begin{array}{l}\text { Dental hygiene } \\
\text { procedures } \\
\quad \uparrow 100 \%(3 / 3)\end{array}$ \\
\hline $\begin{array}{l}26,28,34,35,37, \\
39,40,44,52,53, \\
66,68,76,87,89, \\
95,96,100,101,110, \\
114,115]\end{array}$ & Periodontitis & $\begin{array}{l}\downarrow 66.7 \%(14 / 21) \\
\leftrightarrow 23.8 \%(5 / 21) \\
\uparrow 9.5 \%(2 / 21)\end{array}$ & & $\begin{array}{l}\text { Dental hygiene } \\
\text { procedures or scaling } \\
\text { and root planing } \\
\quad \uparrow 50 \%(3 / 6) \\
\quad \leftrightarrow 50 \%(3 / 6)\end{array}$ \\
\hline $\begin{array}{l}{[13-15,17,22-} \\
24,29,36,49,83, \\
88,92,113,128]\end{array}$ & $\begin{array}{l}\text { Severe oral } \\
\text { diseases }\end{array}$ & $\begin{array}{c}\downarrow 66.7 \%(10 / 15) \\
\leftrightarrow 26.7 \%(4 / 15) \\
\uparrow 6.6 \%(1 / 15) \\
\end{array}$ & & \\
\hline $\begin{array}{l}{[30,31,86,142,154,} \\
158,162,179]\end{array}$ & Renal diseases & $\begin{array}{l}\uparrow 50 \%(2 / 4) \\
\downarrow 50 \%(2 / 4)\end{array}$ & $\begin{array}{l}\downarrow 60 \%(3 / 5) \\
\leftrightarrow 20 \%(1 / 5) \\
\uparrow 20 \%(1 / 5) \\
\end{array}$ & \\
\hline
\end{tabular}

HAART: highly active antiretroviral therapy; TAC: total antioxidant capacity; $\uparrow:$ increase; $\downarrow$ : decrease; $\leftrightarrow$ : unchanged.

infection and TAC depends on the type and on the site of infection.

On the other hand, oxidative stress is implicated in the pathogenesis of many oral diseases and meta-analysis results showed that TAC levels from peripheral blood samples were significantly different between periodontitis (PD) patients and healthy subjects, suggesting that chronic periodontitis is associated with systemic oxidative stress in human bodies [180]. In agreement with this finding, lower values of salivary TAC were found in PD patients versus healthy subjects in $66.7 \%$ of the studies (Table 1). When increased salivary TAC levels were observed, it has been suggested that this increase may represent an adaptive response to oxidative stress in PD [115]. Dental hygiene procedures and scaling and root planing increased salivary TAC in $100 \%$ of the studies conducted on healthy subjects with caries and in $50 \%$ of the studies on patients with PD (Table 1). Therefore, the antioxidant status in saliva is related to both oral hygiene and periodontal status.

On the other hand, $66.7 \%$ of the studies that have investigated the salivary TAC in more serious oral diseases, including recurrent aphthous stomatitis (RAS) (the most common oral ulcerative condition) $[36,88]$, stem cell transplantation- (SCT-) related salivary gland injury due to graft versus host disease (GVHD) [92], oral mucositis induced by high-dose therapy of melphalan in myeloma patients treated with autologous SCT [22], cleft lip and palate [17], oral premalignant lesions (leukoplakia, lichen planus, and erythroplakia) $[13-15,23,29,49,83,113,128]$, and oral cancers $[14,24]$, found decreased levels of salivary TAC in these patients (Table 1). Furthermore, salivary TAC was decreased also in patients with peri-implant disease [81] and in children undergoing fixed orthodontic therapy [54].

Concerning renal status, decreased levels of urinary TAC have been reported in renal diseases including secondary (induced by hypertension and diabetes) and primary renal disease, chronic and acute renal failure, and shockwave lithotripsy- (SWL-) induced acute kidney injury (Table 1).

Decreased urinary TAC has been reported 120 minutes after SWL in both patients with kidneys stone and controls [158], but others reported that SWL did not change urinary TAC measured in the 24-h urine [179]. On the contrary, urinary TAC was higher in childhood urolithiasis and was associated with hyperuricosuria [154].

Chronic renal failure is often treated with peritoneal dialysis and chronic renal failure patients undergoing dialysis are characterized by decreased urinary TAC [142]. However, both increased and decreased salivary TAC was found in these patients $[30,31,86]$ (Table 1 ), probably due to the hyperuricaemia. Kidney transplantation is the treatment of choice for most patients with end-stage renal disease and it has been suggested that urinary biomarkers of oxidative stress could be useful in the assessment of kidney quality before transplantation, which is needed to predict recipient outcomes and to optimize management and allocation of the allograft [181]. In particular, TAC was found to be significantly lower in donor urine for kidneys from poor cadaveric donors, based on clinical impression or renal transplant outcome, compared to urinary TAC of living related donors and good cadaveric donors $[173,174]$. On the other hand, increased urinary TAC was found in patients with delayed graft function, but not with early graft function [174].

\section{Systemic Diseases}

Oxidative stress is associated with the metabolic syndrome, a cluster of cardiovascular risk factors including dyslipidemia, abnormal glucose tolerance, hypertension, and obesity [182]. Despite the antioxidant effect of uric acid (UA), hyperuricaemia is associated with obesity and insulin resistance [183] and has been proposed as a component of the metabolic syndrome [184, 185]. 
TABLE 2: Systemic diseases.

\begin{tabular}{|c|c|c|c|c|}
\hline References & $\begin{array}{c}\text { Case-control } \\
\text { studies }\end{array}$ & $\begin{array}{c}\text { Salivary TAC } \\
\text { percentage }\left(n^{\circ}\right) \\
\end{array}$ & $\begin{array}{c}\text { Urinary TAC } \\
\text { percentage }\left(n^{\circ}\right) \\
\end{array}$ & $\begin{array}{l}\text { Treatment effect } \\
\text { percentage }\left(n^{\circ}\right)\end{array}$ \\
\hline $\begin{array}{l}{[19,37,46,50,55,56,91} \\
100,101,107,119,129,144]\end{array}$ & $\begin{array}{l}\text { Metabolic } \\
\text { syndrome } \\
\text { symptoms }\end{array}$ & $\begin{array}{l}\uparrow 41.7 \%(5 / 12) \\
\leftrightarrow 33.3 \%(4 / 12) \\
\downarrow 25 \%(3 / 12)\end{array}$ & & $\begin{array}{l}\text { Salivary TAC } \\
\quad \leftrightarrow 100 \%(1 / 1) \text { enalapril } \\
\quad \downarrow 100 \%(1 / 1) \text { metoprolol } \\
\quad \downarrow 100 \%(1 / 1) \text { rasburicase } \\
\text { Urinary TAC } \\
\quad \downarrow 100 \%(1 / 1) \text { PCI } \\
\quad \leftrightarrow 100 \%(1 / 1) \text { NAC before and after PCI }\end{array}$ \\
\hline$[59,74,118,152,165]$ & Cancer & $\begin{array}{l}\downarrow 66.7 \%(2 / 3) \\
\uparrow 33.3 \%(1 / 3)\end{array}$ & $\begin{array}{l}\downarrow 66.7 \%(2 / 3) \\
\leftrightarrow 33.3 \%(1 / 3)\end{array}$ & $\begin{array}{l}\text { Salivary TAC } \\
\quad \downarrow \text { chemotherapy }\end{array}$ \\
\hline$[42,105,111,117,150,167]$ & $\begin{array}{c}\text { Neuropsychiatric } \\
\text { disorders }\end{array}$ & $\begin{array}{l}\downarrow 75 \%(3 / 4) \\
\uparrow 25 \%(1 / 4)\end{array}$ & $\downarrow 100 \%(2 / 2)$ & \\
\hline $\begin{array}{l}{[43,82,116,146,151,156,} \\
163,169]\end{array}$ & $\begin{array}{l}\text { Congenital and } \\
\text { genetic diseases }\end{array}$ & $\begin{array}{l}\downarrow 33.3 \%(1 / 3) \\
\leftrightarrow 33.3 \%(1 / 3) \\
\uparrow 33.3 \%(1 / 3) \\
\end{array}$ & $\begin{array}{l}\downarrow 83.3 \%(5 / 6) \\
\uparrow 16.7 \%(1 / 6)\end{array}$ & $\begin{array}{l}\text { Urinary TAC: } \\
\uparrow 100 \%(3 / 3) \text { low-protein diet + } \\
\text { L-carnitine in IEM patients }\end{array}$ \\
\hline $\begin{array}{l}{[33,38,48,58,65,106} \\
108,109,123,126,132,135]\end{array}$ & $\begin{array}{l}\text { Immune mediated } \\
\text { and inflammatory } \\
\text { diseases }\end{array}$ & $\begin{array}{l}\downarrow 60 \%(6 / 10) \\
\uparrow 40 \%(4 / 10)\end{array}$ & & $\begin{array}{l}\text { Salivary TAC } \\
\quad \leftrightarrow 100 \%(1 / 1) \text { corticosteroid } \\
\quad \leftrightarrow 100 \%(2 / 2) \text { CPAP in OSAS } \\
\quad \leftrightarrow 100 \%(1 / 1) \text { anti-TNF } \alpha \text { therapy }\end{array}$ \\
\hline
\end{tabular}

CPAP: continuous positive airway pressure; IEM: inborn errors of metabolism; NAC: N-acetylcysteine; OSAS: obstructive sleep apnea syndrome; PCI: percutaneous coronary intervention; TAC: total antioxidant capacity; TNF $\alpha$ : tumor necrosis factor alpha; $\uparrow$ : increase; $\downarrow$ : decrease; $\leftrightarrow$ : unchanged.

Contrasting results came from the studies that investigated salivary TAC in subjects with at least one of the metabolic syndrome symptoms (Table 2).

Pregnant women with diabetes were found to have increased salivary TAC, but also markedly increased indexes of caries activity [119]. Besides the authors [119] found increased Lactobacillus and Streptococcus species in saliva of pregnant women with diabetes having systemic complications as compared to healthy individuals and other patients. However, increase in salivary TAC was observed also in obese subjects with hyperuricaemia [50] and in obese children despite their good oral hygiene status [56]. While rasburicase infusion decreased salivary TAC [50], intravenous $\mathrm{N}$-acetylcysteine failed to prevent renal dysfunction and oxidative stress after contrast media administration during percutaneous coronary interventions [144] (Table 2). On the other hand, only hypertensive patients in treatment with metoprolol had lower salivary TAC compared to controls [46] (Table 2).

Salivary or urinary TAC was studied also in other diseases, such as cancer, neuropsychiatric disorders, congenital and genetic diseases, and immune mediated and inflammatory diseases (Table 2).

Urinary TAC was decreased in bladder cancer [165] and in nonsmokers with lung cancer [152], but not in smokers with lung cancer. Decreased salivary TAC was observed in patients with squamous cell carcinoma of head and neck [74] and with brain tumor [118], but increased salivary TAC was reported in acute lymphoblastic leukemia (ALL) children [59] (Table 2). Only children with more than 2 weeks of chemotherapy had decreased levels of salivary TAC [59].

Increased levels of salivary TAC were found in patients with neurological disorders and tube-feeding [42], whereas decreased levels were reported in cerebral palsy [117], intractable epilepsy [111], and autistic children [105]. Also urinary TAC levels were lower in autistic compared to healthy children $[150,167]$.

On the other hand, case-control studies on congenital or genetic diseases such as Down syndrome $[43,116]$ and cystic fibrosis [82] reported conflicting results on salivary TAC (Table 2). Besides, Campos et al. [146] found increased and decreased levels of urinary TAC in children and adults with Down syndrome, respectively (Table 2 ). On the contrary, urinary TAC resulted in a good marker of oxidative stress in patients with inborn errors of metabolism (IEM), such as maple syrup urine disease (MSUD), propionic aciduria (PA), methylmalonic aciduria (MMA), 3-hydroxy3-methylglutaric aciduria (HMGA), and ornithine transcarbamylase deficiency (OTC), both before and after treatment (Table 2).

On the other hand, salivary TAC was lower in asthma [58], Crohn's disease [106], multiple sclerosis [65, 135], and Sjögren's syndrome [109] patients compared to healthy individuals (Table 2), but neither corticosteroid therapy, in multiple sclerosis patients [65], nor continuous positive airway pressure (CPAP) in obstructive sleep apnea syndrome (OSAS) improved salivary TAC $[38,123]$. Furthermore, increased salivary TAC levels were found in chronic obstructive pulmonary disease (COPD) [132] and in juvenile idiopathic arthritis (JIA) [33]. Children with JIA, whether treated or not treated with anti-tumor necrosis factor- (TNF-) $\alpha$ agents (Infliximab or Etanercept), had higher salivary TAC and the increase of the active patients was nearly two times higher than that of nonactive patients [33]. Increased salivary TAC levels were found also in pre- and postsurgical patients, where surgical procedures, involving stress such as extended general anaesthesia and a long presurgical fasting period, may cause systemic inflammation and oxidative stress [126]. 
TABLE 3: Nutritional and supplement interventions.

\begin{tabular}{|c|c|c|c|c|}
\hline References & Intervention & $\begin{array}{c}\text { Number of } \\
\text { bolus/repeated } \\
\text { consumptions }\end{array}$ & $\begin{array}{c}\text { Salivary TAC } \\
\text { percentage }\left(n^{\circ}\right)\end{array}$ & $\begin{array}{l}\text { Urinary TAC } \\
\text { percentage }\left(n^{\circ}\right)\end{array}$ \\
\hline $\begin{array}{l}{[80,94,120,127,138,141,} \\
147,168]\end{array}$ & $\begin{array}{l}\text { Caffeinated or } \\
\text { alcoholic } \\
\text { antioxidant } \\
\text { beverages }\end{array}$ & $5 / 4$ & $\begin{array}{l}\uparrow 50 \%(2 / 4) \\
\leftrightarrow 50 \%(2 / 4)\end{array}$ & $\begin{array}{l}\uparrow 40 \%(2 / 5) \\
\leftrightarrow 60 \%(3 / 5)\end{array}$ \\
\hline$[160,166,170]$ & $\begin{array}{l}\text { Cocoa powder } \\
\text { and walnuts }\end{array}$ & $2 / 1$ & & $\uparrow 100 \%(3 / 3)$ \\
\hline $\begin{array}{l}{[137,147,153,155,157,} \\
161,164]\end{array}$ & $\begin{array}{c}\text { Fruit, juices, and } \\
\text { vegetables }\end{array}$ & $6 / 3$ & $\leftrightarrow 100 \%(1 / 1)$ & $\begin{array}{l}\uparrow 62.5 \%(5 / 8) \\
\downarrow 12.5 \%(1 / 8) \\
\leftrightarrow 25 \%(2 / 8) \\
\end{array}$ \\
\hline $\begin{array}{l}{[25,27,64,127,142,147} \\
159,161,171,175-178]\end{array}$ & $\begin{array}{l}\text { Supplements } \\
\text { and } \\
\text { supplemented } \\
\text { foods }\end{array}$ & $4 / 12$ & $\begin{array}{l}\uparrow 50 \%(2 / 4) \\
\leftrightarrow 50 \%(2 / 4)\end{array}$ & $\begin{array}{l}\uparrow 58.3 \%(7 / 12) \\
\leftrightarrow 41.7 \%(5 / 12)\end{array}$ \\
\hline$[32,143,160,164]$ & $\begin{array}{l}\text { Other dietary } \\
\text { interventions }\end{array}$ & $1 / 3$ & $\leftrightarrow 100 \%(1 / 1)$ & $\begin{array}{l}\uparrow 66.7 \%(2 / 3) \\
\leftrightarrow 33.3 \%(1 / 3)\end{array}$ \\
\hline
\end{tabular}

TAC: Total Antioxidant Capacity.

Increased salivary TAC was also observed in Regional Pain Syndrome type I [48], whereas decreased salivary TAC levels were reported in temporomandibular disorders [108].

\section{Nutritional and Supplement Interventions}

Although body possesses a sophisticated and cooperative array of endogenous antioxidant defenses, dietary consumption of antioxidant-rich foods may lower the risk of noncommunicable diseases, by increasing TAC. In fact, $70 \%$ of the interventions with plant foods or supplements conducted on subjects characterized by oxidative stress conditions such as cardiovascular risk factors (smoking, hypercholesterolemia, metabolic syndrome, hyperlipidemia, and hypertension) or with pathologies reported an increase of plasma/serum TAC [186]. In the studies that investigated the effect of dietary or supplementation interventions on salivary or urinary TAC (Table 3), volunteers were prevalently healthy; however, in some studies, overweight (OW) [164] or elderly [94, 143, 147,153 ] subjects, smokers [25], or patients with PD [137] or dialyzed [142] were enrolled. A review of 41 interventions, from 29 studies, has been performed (Table 3). Of these interventions, 18 regard a single ingestion (bolus) and the other 23 were related to repeated supplementations.

Caffeinated or alcoholic antioxidant beverages increased salivary TAC in $50 \%$ and urinary TAC in $40 \%$ of the interventions. In particular, green tea (GT) consumption for 4 or 12 weeks increased salivary TAC in laboratory workers and elderly subjects $[94,120]$, whereas it did not affect salivary TAC of Taekwondo (TKD) athletes after training [80]. Besides, Benzie et al. [141] found a significant correlation between urinary FRAP values and urinary total phenolic concentrations after GT consumption. Red wine bolus consumption did not change salivary TAC [127] but increased urinary TAC in elderly women [147]. After a single or 2 weeks of consumption of green or black coffee urinary TAC did not change $[138,168]$.

On the other hand, walnuts $[160,166]$ increased urinary TAC both after 4 weeks and after a single consumption and cocoa increased urinary TAC at 6-12 h after intake concomitantly with the excretion of epicatechin urinary metabolites [170] (Table 3).

Concerning fruit, juices, and vegetables, only Zare Javid et al. [137] investigated the effect of fruits, vegetables, and whole grains (3 and 6 months) consumption on salivary TAC of PD patients and did not find any change in this marker. Only one study reported decreased urinary TAC levels after a single consumption of blackberry juices [157]. On the contrary, urinary TAC increased after bolus consumption of spinach [147], strawberries [147], Jerte Valley cherry [153], and a fruit based drink ( $86 \%$ of a mix of apple, grape, blueberry and pomegranate juices and grape skin, grape seed, and green tea extracts) ingested during a high fat meal (HFM) [164]. In the same postprandial study, a less antioxidant fruit based drink (63\% of a mix of pineapple, black currant, and plum juices) during HFM did not affect urinary TAC, a well as plasma TAC [164]. Also grape juice consumption for 5 days increased urinary TAC [155], whereas tomato juice consumption for 2 weeks did not [161]. The same study found increased urinary TAC levels when tomato juice was supplemented with vitamin C $(870 \mathrm{mg} / \mathrm{L})$ fortification [161]. Vitamin C (250 mg) with vitamin E (400i.u.) supplementation for 8 weeks increased urinary TAC in dialyzed patients [142] and vitamin $\mathrm{C}$ in bolus administration increased urinary TAC in elderly women $(1250 \mathrm{mg})$ [147] and salivary TAC in healthy subjects $(250 \mathrm{mg}$ ) [64]. On the contrary neither vitamin C after 3 weeks $(500 \mathrm{mg}$ ) of consumption in smokers [25] nor 90 days of astaxanthin supplementation in trained male soccer players in preexercise conditions [27] changed salivary TAC. 
TABLE 4: Life-style factors.

\begin{tabular}{|c|c|c|c|}
\hline References & Factor & $\begin{array}{c}\text { Salivary TAC } \\
\text { percentage }\left(n^{\circ}\right)\end{array}$ & $\begin{array}{c}\text { Urinary TAC } \\
\text { percentage }\left(n^{\circ}\right)\end{array}$ \\
\hline$[21,80,85,134,140]$ & Exercise & $\begin{array}{l}\downarrow 75 \%(3 / 4) \\
\uparrow 25 \%(1 / 4)\end{array}$ & $\downarrow 100 \%(1 / 1)$ \\
\hline $\begin{array}{l}{[32,35,41,53,71,77} \\
93,132,136,138,145]\end{array}$ & Smoking habit & $\begin{array}{c}\uparrow 20 \%(2 / 10) \\
\leftrightarrow 50 \%(5 / 10) \\
\downarrow 30 \%(3 / 10)\end{array}$ & $\leftrightarrow 100 \%(1 / 1)$ \\
\hline [102] & $\begin{array}{c}\text { Alcohol } \\
\text { dependence }\end{array}$ & $\downarrow 100 \%(1 / 1)$ & \\
\hline$[51,139]$ & $\begin{array}{l}\text { Occupational } \\
\text { exposure to } \\
\text { toxicants }\end{array}$ & $\downarrow 100 \%(1 / 1)$ & $\uparrow 100 \%(1 / 1)$ \\
\hline$[18,20,57,67]$ & $\begin{array}{l}\text { Cell phone and } \\
\text { watching TV }\end{array}$ & $\begin{array}{l}\uparrow 75 \%(3 / 4) \\
\downarrow 25 \%(1 / 4) \\
\end{array}$ & \\
\hline
\end{tabular}

TAC: Total Antioxidant Capacity.

Conversely, red wine extract administration caused a marked rise in salivary TAC, within $30 \mathrm{~min}$, and the same treatment raised also salivary polyphenol concentration [127]. Helbig et al. [159] reported the same increase in urinary TAC versus baseline with both control bread and bread enriched with black currant press residue (4 weeks). Besides, urinary TAC was unchanged after 21 days consumption of a dried fruit and vegetable extracts fortified with antioxidants [176], after 2 weeks of Pycnogenol ( $200 \mathrm{mg} /$ day) supplementation [175] and after 24 days of administration of an antioxidant mixture containing vitamin $\mathrm{E}$, beta-carotene, ascorbic acid, selenium, alpha-lipoic acid, $\mathrm{N}$-acetyl 1-cysteine, catechin, lutein, and lycopene [171]. On the contrary, ganoderma lucidum (Lingzhi, woody mushroom) supplements increased urinary TAC both in bolus and in repeated administration $[177,178]$.

Concerning other dietary interventions, a low fat diet did not affect salivary TAC compared to a high fat diet [32] and a HFM did not affect urinary TAC [164]. On the contrary, a fish diet ( $8 \mathrm{oz} /$ week of salmon) for 4 weeks [160] and the consumption of tryptophan-enriched cereals for 1 week [143] increased urinary TAC.

\section{Age, Gender, and lifestyle Factors}

Age and gender differences were observed in oxidative stress markers in plasma [187]. It was found that salivary TAC increased with the age of the children with caries [60], as well as during aging $[62,69]$. On the contrary, others reported that salivary TAC was higher in younger subjects [73] and negative correlations with age were found for urinary TAC [146]. Women had significantly lower salivary TAC than men $[79,110,114]$. In this context Kawamoto et al. [66] reported decreased levels of salivary TAC during the ovulatory phase compared to follicular phase in women with $\mathrm{PD}$, but not in healthy women. TAC was negatively correlated with bacterial counts during the ovulatory phase, but not during the follicular phase [66]. Besides, salivary TAC was lower during uncomplicated pregnancy [70] and in osteoporotic subjects compared to age-matched healthy women [133].
Apart from age, gender, diseases, and dietary habit, also lifestyle factors could affect salivary and urinary TAC. Within lifestyle factors, many studies investigated the effect of exercise and smoking habit on salivary or urinary TAC (Table 4).

In agreement with the well-known reduction of antioxidant defenses after physical stress, strong correlation was found between the variations of salivary and plasma TAC during the training season in triathletes [134]. Both $2 \mathrm{hr}$ TKD training session and $1 \mathrm{hr}$ exhaustive aerobic dance exercise decreased salivary TAC $[21,80]$. Besides also urinary TAC decreased after 3 hours or more of TKD training camp/d for 5-8 days [140]. Only a study found increased salivary TAC in older adults with $\mathrm{PD}$ who performed Tai Chi during a period of 6 months; however this increase was accompanied by a statistically significant decrease in the Periodontal Disease Index (PDI) [85].

More conflicting are results on smoking habit; higher, lower, or nonsignificant different levels of salivary TAC have been found in smokers compared to nonsmokers, whereas no significant differences were found in urinary TAC between smokers and nonsmokers (Table 4).

On the contrary, alcohol-dependent subjects showed significantly lower TAC in blood and saliva as compared to those in the controls and the alcohol withdrawal caused an increase in the TAC to near-control values [102].

Decreased levels of salivary TAC were found also in workers subjected to occupational exposure to nonferrous metal mine conditions [51], whereas exposure to trichloroethylene increased urinary TAC [139].

Although there was no statistically significant effect of cell phone talking time on the salivary TAC, the latter progressively increased with time and reached maximum at $30 \mathrm{~min}$, probably due to exposure to radio frequency radiation [67]. However, both increased [57] and decreased [18] levels of salivary TAC in mobile phone users were found.

On the other hand, it has been observed that salivary TAC was affected by emotional and psychological factors [20]. In particular, watching a cheerful comical video for $30 \mathrm{~min}$ increased salivary TAC [20]. 


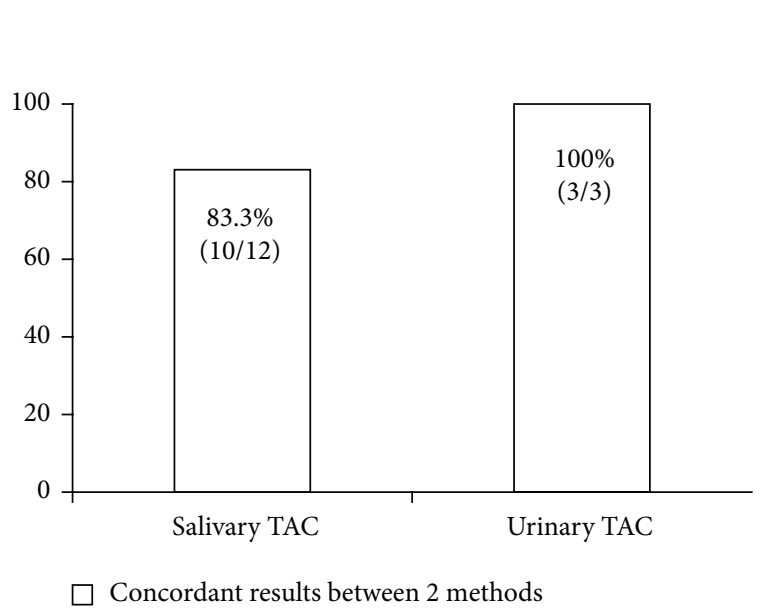

(a)

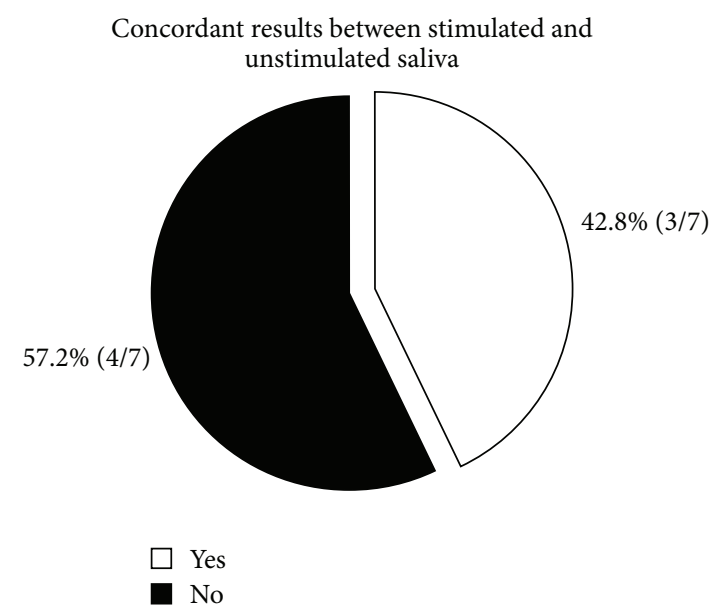

(b)

Figure 1: Concordat results between two different methods used in the same study to measure salivary or urinary TAC (a). Concordant results between unstimulated and stimulated saliva samples analyzed in the same study (b). References $[22,24,34,38,50,62,64,65,67,72$, $78,81,111,127,135,137,161,166,175,188-190]$.

\section{Methodological Issues}

Despite the differences between the assays [8], concordant results were found in the majority of the cases between the results obtained when two different methods (Trolox Equivalent Antioxidant Capacity (TEAC), Ferric Reducing Antioxidant Potential (FRAP), Oxygen Radical Antioxidant Capacity (ORAC), Total-radical Trapping Antioxidant Parameter (TRAP), or enzyme-linked immunosorbent assay (ELISA) colorimetric kit) were used in the same study to measure salivary or urinary TAC (Figure 1(a)).

In particular, although FRAP was significantly lower in multiple sclerosis patients, whereas no significant difference in salivary TEAC between patients and controls was observed [65], the authors pointed out that their study had some limitations, such as the low number of patients included, the variability of the clinical status, and the different treatment of patients. Therefore, method choice does not seem to be a critical point for salivary TAC measure. On the contrary, major concerns came from saliva collection (Figure 1(b)).

Saliva sampling has been improved by cotton and polypropylene Salivette collection systems, but the latter altered the determination of some markers [188]. It has been reported that in samples collected using the cotton Salivette TAC was comparable, but higher thiobarbituric acid reacting substances (TBARS) concentrations were determined compared with unstimulated saliva [188].

In healthy subjects values were higher under stimulated conditions for saliva flow and were higher under unstimulated conditions with respect to TAC and UA [189]. When TAC was examined with respect to flow rate, a significantly lower rate of antioxidant production was noted in patients with PD compared with controls for unstimulated saliva but not for stimulated saliva [34]. Besides, a significant decrease in UA and TAC was observed in unstimulated saliva as well as a significant increase in all antioxidants examined in stimulated saliva of systemic sclerosis women with normal salivary flow rate as compared to the healthy controls [135].

Nagler et al. [190] examined the correlation between the levels of various salivary antioxidant components and the TAC in whole saliva in comparison with those in saliva secreted specifically from the major salivary glands: the parotid and the submandibular/sublingual ( $\mathrm{Sm} \_\mathrm{Sl}$ ) glands. While the secretory IgA and lysozyme concentrations were similar in parotid and Sm_Sl saliva, the authors [190] found higher levels of the various antioxidant parameters (antioxidant enzymes, UA and TAC) in the parotid saliva as compared with the Sm_Sl saliva, especially under resting condition. Under resting condition parotid saliva was the major source of salivary antioxidants, especially of UA [190]. After stimulation (i.e., eating), the various parameters of antioxidants of parotid saliva were considerably reduced, in light of the well-reported "dilution effect" that follows stimulation. In addition, fluids by nonglandular sources contributed to the possible dilution of the whole saliva, after meal. Therefore, unstimulated saliva with and without flow rate normalization could be the better approaches to measure salivary TAC.

Also urine can be more or less diluted, complicating the evaluation of parameters in spontaneous urine. Particularly after physical stress [140] more concentrated urine is to be expected due to sweating. In order to obviate this problem and provided that the creatinine excretion is relatively constant over $24 \mathrm{~h}$, the mean creatinine excretion can serve as a reference for the measured values of excretion. Generally, an average creatinine excretion of $1 \mathrm{~g} / 24 \mathrm{~h}$ is assumed [140]. However, it must be taken into consideration that age, sex, muscle mass, and diet all have an influence on creatinine excretion [191]. Although analyzing $24 \mathrm{~h}$ urine collection would have been preferable in case-control studies, it was logistically impossible in some cases. On the other hand, $24 \mathrm{~h}$ urine collection could not appreciate the increase in TAC due to intervention with polyphenol-rich foods, considering 


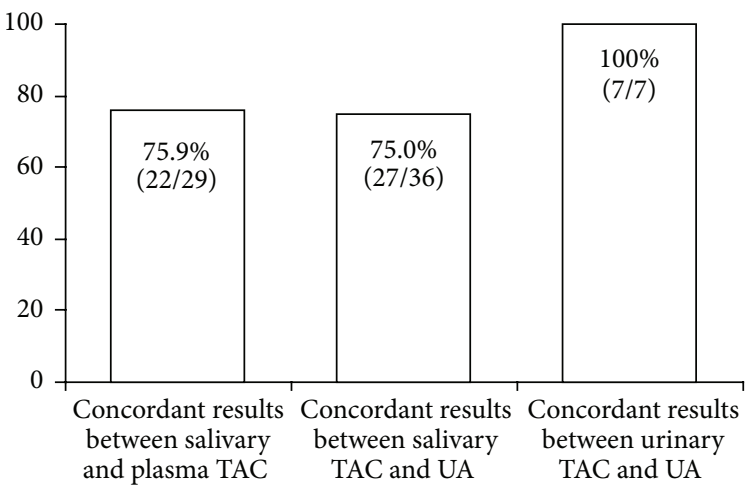

Case-control

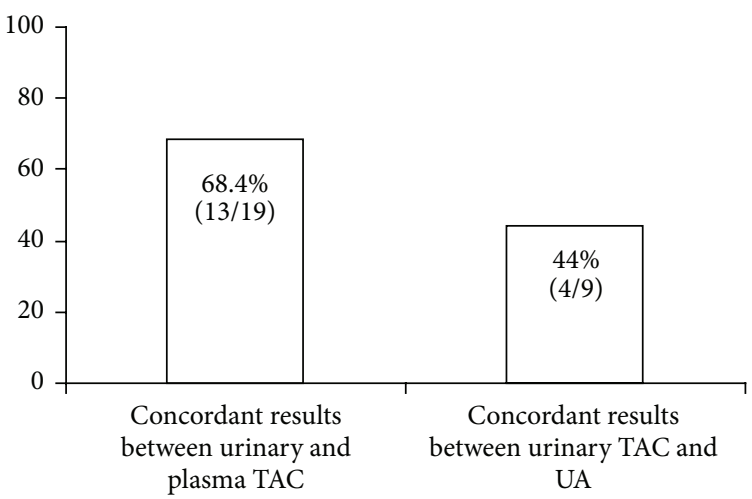

Interventions

(a)

(b)

FIgURE 2: Concordant results between salivary or urinary TAC and UA levels or plasma TAC in case-control (a) or antioxidant/nutritional intervention (b) studies. References $[17,19,21-24,26,28-31,34,37,38,40-44,48-51,55,57,61,62,65,71,77,78,81,82,86-89,91,92,95-$ 97, 102, 106-111, 119, 126, 132-136, 140-142, 144, 146, 147, 150, 154, 157, 159-162, 164, 166, 171, 175-178].

the rate of elimination of polyphenols [12]. Therefore, $24 \mathrm{~h}$ or spontaneous urine collection should be chosen on the basis of the study outcome and of the creatinine clearance.

\section{Uric Acid-Independent TAC versus TAC}

UA is a powerful scavenger of free radicals and provides $60-$ $80 \%$ of TAC in plasma $[192,193]$. It has been also reported that TAC of both plasma and urine is mainly related to the UA concentration of the samples [194]. Besides, UA contributes approximately $70 \%$ of the salivary TAC [89], with the antioxidant role of the ascorbic acid being secondary [89] and correlation between concentrations of UA in both saliva and plasma points to the latter as the origin of salivary UA $[71,190]$. According to this hypothesis, when salivary or urinary TAC, UA, and plasma or serum TAC were measured in the same study, it turned out that there was a clear accordance between UA concentration and TAC, as well as between salivary or urinary TAC and plasma or serum TAC in case-control studies (Figure 2(a)). Furthermore, rasburicase i.v. infusion in obese subjects with hyperuricaemia caused a marked decrease in both plasma and saliva TAC values [50].

Increase in serum UA levels can be due to increased intake of dietary purines, alcohol and fructose [195], impaired renal function and renal microvascular disease, which can increase UA production and/or decrease UA clearance [196], and hyperinsulinemia, which increases renal UA reabsorption [197]. In particular, the plasma level of UA is regulated by renal function [162]. However, although urine from renal disease patients had more proteins and UA compared to controls, urinary TAC from acute renal failure patients did not correlate with UA [162]. Furthermore, contrasting results came from patients with severe chronic renal failure (CRF) (dialytic) without diabetes and severe CRF (dialytic) with diabetes [30]. In severe-CRF patients without diabetes, median TAC and UA levels decreased following dialysis, whereas in severe-CRF patients with diabetes, median TAC increased following dialysis while median UA decreased [30].
Although UA in urine samples constitutes about $75 \%$ of urinary TAC [140], the composition of urine is unpredictable, reflecting the continuously changing environment of the body, which is affected, among other factors, by diet [162]. In fact, only in $44 \%$ (4/9) of the interventions with antioxidant foods, beverages or supplements urinary TAC was related to UA (Figure 1(b)). These findings are probably due to the fact that low molecular weight antioxidants, such as polyphenols, are cleared from the blood by kidney [12]. The only study that [137] investigated the effect of fruits, vegetables, and whole grains consumption on both salivary and plasma TAC did not find any change in salivary TAC, despite the increase in plasma TAC.

In order to avoid the UA interference, methods for UAindependent TAC have been proposed, by using the uricase reaction, in both plasma and urine [198], or by using the corrected TAC, the calculated parameter that represents the fraction of circulating antioxidants after the elimination of the interference of UA $[140,199]$.

Similar calculated urinary TAC has been proposed by Campos et al. [146]. Authors suggested that TAC-UA/Cr could provide more reliable information about the antioxidant status, at least in Down syndrome, because children had higher TAC/Cr and UA/Cr, whereas levels of TAC-UA/Cr of adult patients were lower compared to healthy subjects.

On the contrary, uricase methods could be biased by the generation of $\mathrm{H}_{2} \mathrm{O}_{2}$ during the action of uricase [200]. Therefore, the calculated corrected TAC-UA could be the better approach.

\section{Conclusion}

The reviewed case-control and intervention studies that measured salivary or urinary TAC revealed that these markers can be useful in the evaluation of the antioxidant status of the body taking into account some factors. First of all, salivary and urinary TAC were particularly affected by oral or renal status, respectively, as well as by infection 
(Table 1); therefore these factors could bias results in some studies [66, 85, 119]. Second, samples collection (Figure 1) and normalization strategies should be chosen on the basis of the type of biological fluid, of the study outcome, and of the creatinine clearance. Again, TAC is related to both UA (Figure 2) and nutritional antioxidant levels in biological fluids $[127,141,147,170]$. From that, the UA-independent TAC could be the better approach to evaluate red-ox status of body both after nutritional interventions and in diseases associated with hyperuricaemia. Finally, TAC is sensitive also to the endogenous antioxidant response induced by some pathological and environmental conditions $[20,33,48,57,59$, $67,115,126,132,139,142]$.

\section{Conflict of Interests}

The authors declare that there is no conflict of interests regarding the publication of this paper.

\section{References}

[1] K.-H. Wagner and H. Brath, "A global view on the development of non communicable diseases," Preventive Medicine, vol. 54, supplement, pp. S38-S41, 2012.

[2] J. Limón-Pacheco and M. E. Gonsebatt, "The role of antioxidants and antioxidant-related enzymes in protective responses to environmentally induced oxidative stress," Mutation Research/Genetic Toxicology and Environmental Mutagenesis, vol. 674, no. 1-2, pp. 137-147, 2009.

[3] M. Valko, D. Leibfritz, J. Moncol, M. T. D. Cronin, M. Mazur, and J. Telser, "Free radicals and antioxidants in normal physiological functions and human disease," International Journal of Biochemistry and Cell Biology, vol. 39, no. 1, pp. 44-84, 2007.

[4] E. Niki, "Assessment of antioxidant capacity in vitro and in vivo," Free Radical Biology and Medicine, vol. 49, no. 4, pp. 503-515, 2010.

[5] G. Bartosz, "Non-enzymatic antioxidant capacity assays: limitations of use in biomedicine," Free Radical Research, vol. 44, no. 7, pp. 711-720, 2010.

[6] S. Knasmüller, A. Nersesyan, M. Mišík et al., "Use of conventional and -omics based methods for health claims of dietary antioxidants: a critical overview," British Journal of Nutrition, vol. 99, supplement 1, pp. ES3-ES52, 2008.

[7] I. Pinchuk, H. Shoval, Y. Dotan, and D. Lichtenberg, "Evaluation of antioxidants: scope, limitations and relevance of assays," Chemistry and Physics of Lipids, vol. 165, no. 6, pp. 638-647, 2012.

[8] V. Dilis and A. Trichopoulou, "Assessment of antioxidants in foods and biological samples: a short critique," International Journal of Food Sciences and Nutrition, vol. 61, no. 5, pp. 441448, 2010.

[9] G. Cao and R. L. Prior, "Comparison of different analytical methods for assessing total antioxidant capacity of human serum," Clinical Chemistry, vol. 44, no. 6, part 1, pp. 1309-1315, 1998.

[10] C. Campos, R. Guzmán, E. López-Fernández, and Á. Casado, "Evaluation of the copper(II) reduction assay using bathocuproinedisulfonic acid disodium salt for the total antioxidant capacity assessment: the CUPRAC-BCS assay," Analytical Biochemistry, vol. 392, no. 1, pp. 37-44, 2009.
[11] M. Greabu, M. Battino, M. Mohora et al., "Could constitute saliva the first line of defence against oxidative stress?" Romanian Journal of Internal Medicine, vol. 45, no. 2, pp. 209-213, 2007.

[12] J. Pérez-Jiménez, J. Hubert, L. Hooper et al., "Urinary metabolites as biomarkers of polyphenol intake in humans: a systematic review," The American Journal of Clinical Nutrition, vol. 92, no. 4, pp. 801-809, 2010.

[13] H. Abdolsamadi, N. Rafieian, M. T. Goodarzi et al., "Levels of salivary antioxidant vitamins and lipid peroxidation in patients with oral lichen planus and healthy individuals," Chonnam Medical Journal, vol. 50, no. 2, pp. 58-62, 2014.

[14] F. Agha-Hosseini, I. Mirzaii-Dizgah, N. Farmanbar, and M. Abdollahi, "Oxidative stress status and DNA damage in saliva of human subjects with oral lichen planus and oral squamous cell carcinoma," Journal of Oral Pathology and Medicine, vol. 41, no. 10, pp. 736-740, 2012.

[15] F. Agha-Hosseini, I. Mirzaii-Dizgah, S. Mikaili, and M. Abdollahi, "Increased salivary lipid peroxidation in human subjects with oral lichen planus," International Journal of Dental Hygiene, vol. 7, no. 4, pp. 246-250, 2009.

[16] F. Ahmadi-Motamayel, M.-T. Goodarzi, S.-S. Hendi, S. Kasraei, and A. Moghimbeigi, "Total antioxidant capacity of saliva and dental caries," Medicina Oral, Patología Oral y Cirugía Bucal, vol. 18, no. 4, pp. e553-e556, 2013.

[17] D. Aizenbud, Y. Peri-Front, and R. M. Nagler, "Salivary analysis and antioxidants in cleft lip and palate children," Archives of Oral Biology, vol. 53, no. 6, pp. 517-522, 2008.

[18] F. Arbabi-Kalati, S. Salimi, A. Vaziry-Rabiee, and M. Noraeei, "Effect of mobile phone usage time on total antioxidant capacity of saliva and salivary immunoglobulin A," Iranian Journal of Public Health, vol. 43, no. 4, pp. 480-484, 2014.

[19] F. Astaneie, M. Afshari, A. Mojtahedi et al., "Total antioxidant capacity and levels of epidermal growth factor and nitric oxide in blood and saliva of insulin-dependent diabetic patients," Archives of Medical Research, vol. 36, no. 4, pp. 376-381, 2005.

[20] T. Atsumi, S. Fujisawa, Y. Nakabayashi, T. Kawarai, T. Yasui, and K. Tonosaki, "Pleasant feeling from watching a comical video enhances free radical-scavenging capacity in human whole saliva," Journal of Psychosomatic Research, vol. 56, no. 3, pp. 377379, 2004.

[21] T. Atsumi, I. Iwakura, Y. Kashiwagi, S. Fujisawa, and T. Ueha, "Free radical scavenging activity in the nonenzymatic fraction of human saliva: a simple DPPH assay showing the effect of physical exercise," Antioxidants and Redox Signaling, vol. 1, no. 4, pp. 537-546, 1999.

[22] I. Avivi, S. Avraham, M. Koren-Michowitz et al., "Oral integrity and salivary profile in myeloma patients undergoing high-dose therapy followed by autologous SCT,' Bone Marrow Transplantation, vol. 43, no. 10, pp. 801-806, 2009.

[23] A. Azizi and F. Farshchi, "Comparison of salivary and plasma antioxidant levels in lichen planus patients and healthy subjects," Journal of Oral Pathology and Medicine, vol. 41, no. 7, pp. 524-526, 2012.

[24] G. Bahar, R. Feinmesser, T. Shpitzer, A. Popovtzer, and R. M. Nagler, "Salivary analysis in oral cancer patients: DNA and protein oxidation, reactive nitrogen species, and antioxidant profile," Cancer, vol. 109, no. 1, pp. 54-59, 2007.

[25] S. Bakhtiari, J. B. Taheri, M. Bakhshi et al., "Effect of vitamin C on salivary total antioxidant capacity in smokers," Iranian Journal of Pharmaceutical Research, vol. 11, no. 4, pp. 1045-1049, 2012. 
[26] E. Baltacıoğlu, P. Yuva, G. Aydın et al., "Lipid peroxidation levels and total oxidant/antioxidant status in serum and saliva from patients with chronic and aggressive periodontitis. Oxidative stress index: a new biomarker for periodontal disease?" Journal of Periodontology, vol. 85, no. 10, pp. 1432-1441, 2014.

[27] I. Baralic, M. Andjelkovic, B. Djordjevic et al., "Effect of astaxanthin supplementation on salivary IgA, oxidative stress, and inflammation in young soccer players," Evidence-Based Complementary and Alternative Medicine, vol. 2015, Article ID 783761, 9 pages, 2015.

[28] U. Baser, H. Gamsiz-Isik, E. Cifcibasi, E. Ademoglu, and F. Yalcin, "Plasma and salivary total antioxidant capacity in healthy controls compared with aggressive and chronic periodontitis patients," Saudi Medical Journal, vol. 36, no. 7, pp. 856-861, 2015.

[29] M. Battino, M. Greabu, A. Totan et al., "Oxidative stress markers in oral lichen planus," BioFactors, vol. 33, no. 4, pp. 301-310, 2008.

[30] I. Ben-Zvi, Y. Green, F. Nakhoul, Y. Kanter, and R. M. Nagler, "Effects of diabetes mellitus, chronic renal failure and hemodialysis on serum and salivary antioxidant status," NephronClinical Practice, vol. 105, no. 3, pp. cl14-c120, 2007.

[31] G. Bibi, Y. Green, and R. M. Nagler, "Compositional and oxidative analysis in the saliva and serum of predialysis chronic kidney disease patients and end-stage renal failure patients on peritoneal dialysis," Therapeutic Apheresis and Dialysis, vol. 12, no. 2, pp. 164-170, 2008.

[32] M. Bogucka, J. Giebułtowicz, K. Zawada et al., "The oxidation status of ALDH3A1 in human saliva and its correlation with antioxidant capacity measured by orac method," Acta Poloniae Pharmaceutica, vol. 66, no. 5, pp. 477-482, 2009.

[33] R. Brik, I. Rosen, D. Savulescu, I. Borovoi, M. Gavish, and R. Nagler, "Salivary antioxidants and metalloproteinases in juvenile idiopathic arthritis," Molecular Medicine, vol. 16, no. 34, pp. 122-128, 2010.

[34] G. R. Brock, C. J. Butterworth, J. B. Matthews, and I. L. C. Chapple, "Local and systemic total antioxidant capacity in periodontitis and health," Journal of Clinical Periodontology, vol. 31, no. 7, pp. 515-521, 2004.

[35] N. Buduneli, L. Kardeşler, H. Işik et al., "Effects of smoking and gingival inflammation on salivary antioxidant capacity," Journal of Clinical Periodontology, vol. 33, no. 3, pp. 159-164, 2006.

[36] F. Çağlayan, Ö. Miloglu, O. Altun, Ö. Erel, and A. B. Yilmaz, "Oxidative stress and myeloperoxidase levels in saliva of patients with recurrent aphthous stomatitis," Oral Diseases, vol. 14, no. 8, pp. 700-704, 2008.

[37] V. Canakci, A. Yildirim, C. F. Canakci, A. Eltas, Y. Cicek, and H. Canakcit, "Total antioxidant capacity and antioxidant enzymes in serum, saliva, and gingival crevicular fluid of preeclamptic women with and without periodontal disease," Journal of Periodontology, vol. 78, no. 8, pp. 1602-1611, 2007.

[38] P. Celec, J. Hodosy, M. Behuliak et al., "Oxidative and carbonyl stress in patients with obstructive sleep apnea treated with continuous positive airway pressure," Sleep and Breathing, vol. 16, no. 2, pp. 393-398, 2012.

[39] V. Celecová, N. Kamodyová, L. Tóthová, M. Kúdela, and P. Celec, "Salivary markers of oxidative stress are related to age and oral health in adult non-smokers," Journal of Oral Pathology and Medicine, vol. 42, no. 3, pp. 263-266, 2013.

[40] I. L. C. Chapple, G. I. Mason, I. Garner et al., "Enhanced chemiluminescent assay for measuring the total antioxidant capacity of serum, saliva and crevicular fluid," Annals of Clinical Biochemistry, vol. 34, part 4, pp. 412-421, 1997.
[41] K. Charalabopoulos, D. Assimakopoulos, S. Karkabounas, V. Danielidis, D. Kiortsis, and A. Evangelou, "Effects of cigarette smoking on the antioxidant defence in young healthy male volunteers," International Journal of Clinical Practice, vol. 59, no. 1, pp. 25-30, 2005.

[42] A. S. Cunha-Correia, A. H. Neto, A. F. Pereira, S. M. H. C. Á. Aguiar, and A. C. D. M. S. Nakamune, "Enteral nutrition feeding alters antioxidant activity in unstimulated whole saliva composition of patients with neurological disorders," Research in Developmental Disabilities, vol. 35, no. 6, pp. 1209-1215, 2014.

[43] M. C. de Sousa, R. B. Vieira, D. S. Dos Santos et al., "Antioxidants and biomarkers of oxidative damage in the saliva of patients with Down's syndrome," Archives of Oral Biology, vol. 60, no. 4, pp. 600-605, 2015.

[44] R. Diab-Ladki, B. Pellat, and R. Chahine, "Decrease in the total antioxidant activity of saliva in patients with periodontal diseases," Clinical Oral Investigations, vol. 7, no. 2, pp. 103-107, 2003.

[45] R. A. DiSilvestro, D. J. DiSilvestro, and D. J. DiSilvestro, "Pomegranate extract mouth rinsing effects on saliva measures relevant to gingivitis risk," Phytotherapy Research, vol. 23, no. 8, pp. 1123-1127, 2009.

[46] L. Djukić, J. Roganović, M. D. Brajović, D. Bokonjić, and D. Stojić, "The effects of anti-hypertensives and type 2 diabetes on salivary flow and total antioxidant capacity," Oral Diseases, vol. 21, no. 5, pp. 619-625, 2015.

[47] R. Dodwad, A. V. Betigeri, and B. P. Preeti, "Estimation of total antioxidant capacity levels in saliva of caries-free and cariesactive children," Contemporary Clinical Dentistry, vol. 2, no. 1, pp. 17-20, 2011.

[48] E. Eisenberg, S. Shtahl, R. Geller et al., "Serum and salivary oxidative analysis in Complex Regional Pain Syndrome," Pain, vol. 138, no. 1, pp. 226-232, 2008.

[49] S. Ergun, Ş. C. Troşala, S. Warnakulasuriya et al., "Evaluation of oxidative stress and antioxidant profile in patients with oral lichen planus," Journal of Oral Pathology and Medicine, vol. 40, no. 4, pp. 286-293, 2011.

[50] E. Fabbrini, M. Serafini, I. Colic Baric, S. L. Hazen, and S. Klein, "Effect of plasma uric acid on antioxidant capacity, oxidative stress, and insulin sensitivity in obese subjects," Diabetes, vol. 63, no. 3, pp. 976-981, 2014.

[51] M. Greabu, A. Didilescu, L. Puiu, D. Miricescu, and A. Totan, "Salivary antioxidant biomarkers in non-ferrous metals mine workers-a pilot study," Journal of Oral Pathology and Medicine, vol. 41, no. 6, pp. 490-493, 2012.

[52] M. Greabu, M. Purice, A. Totan, T. Spînu, and C. Totan, "Salivary cortisol-marker of stress response to different dental treatment," Romanian Journal of Internal Medicine, vol. 44, no. 1, pp. 49-59, 2006.

[53] A. Guentsch, P. M. Preshaw, S. Bremer-Streck, G. Klinger, E. Glockmann, and B. W. Sigusch, "Lipid peroxidation and antioxidant activity in saliva of periodontitis patients: effect of smoking and periodontal treatment," Clinical Oral Investigations, vol. 12, no. 4, pp. 345-352, 2008.

[54] C. Guler, E. Toy, F. Ozturk, D. Gunes, A. B. Karabulut, and O. Otlu, "Evaluation of salivary total oxidant-antioxidant status and DNA damage of children undergoing fixed orthodontic therapy," The Angle Orthodontist, vol. 85, no. 2, pp. 239-244, 2015.

[55] P. Gümüş, N. Buduneli, Ş. Çetinkalp et al., "Salivary antioxidants in patients with type 1 or 2 diabetes and inflammatory 
periodontal disease: a case-control study," Journal of Periodontology, vol. 80, no. 9, pp. 1440-1446, 2009.

[56] G. Gunjalli, K. N. Kumar, S. K. Jain, S. K. Reddy, G. R. Shavi, and S. L. Ajagannanavar, "Total salivary anti-oxidant levels, dental development and oral health status in childhood obesity," Journal of International Oral Health, vol. 6, no. 4, pp. 63-67, 2014.

[57] Y. Hamzany, R. Feinmesser, T. Shpitzer et al., "Is human saliva an indicator of the adverse health effects of using mobile phones?" Antioxidants and Redox Signaling, vol. 18, no. 6, pp. 622-627, 2013.

[58] A. M. Hegde, K. Raj, and S. Shetty, "Relation of caries status on the salivary total antioxidant levels in asthmatic children," Contemporary Clinical Dentistry, vol. 3, no. 4, pp. 402-405, 2012.

[59] A. M. Hegde, S. Joshi, K. Rai, and S. Shetty, "Evaluation of oral hygiene status, salivary characteristics and dental caries experience in Acute Lymphoblastic Leukemic (ALL) children," Journal of Clinical Pediatric Dentistry, vol. 35, no. 3, pp. 319-323, 2011.

[60] A. M. Hegde, K. Rai, and V. Padmanabhan, "Total antioxidant capacity of saliva and its relation with early childhood caries and rampant caries," Journal of Clinical Pediatric Dentistry, vol. 33, no. 3, pp. 231-234, 2009.

[61] M. N. Hegde, N. D. Hegde, A. Ashok, and S. Shetty, "Evaluation of total antioxidant capacity of saliva and serum in caries-free and caries-active adults: an in-vivo study," Indian Journal of Dental Research, vol. 24, no. 2, pp. 164-167, 2013.

[62] O. Hershkovich, I. Shafat, and R. M. Nagler, "Age-related changes in salivary antioxidant profile: possible implications for oral cancer," Journals of Gerontology, Series A: Biological Sciences and Medical Sciences, vol. 62, no. 4, pp. 361-366, 2007.

[63] N. Kamodyová, G. Minárik, J. Hodosy, and P. Celec, "Single consumption of Bryndza cheese temporarily affects oral microbiota and salivary markers of oxidative stress," Current Microbiology, vol. 69, no. 5, pp. 716-724, 2014.

[64] N. Kamodyová, L. Tóthová, and P. Celec, "Salivary markers of oxidative stress and antioxidant status: influence of external factors," Disease Markers, vol. 34, no. 5, pp. 313-321, 2013.

[65] M. Karlík, P. Valkovič, V. Hančinová, L. Krížová, L. Tóthová, and P. Celec, "Markers of oxidative stress in plasma and saliva in patients with multiple sclerosis," Clinical Biochemistry, vol. 48, no. 1-2, pp. 24-28, 2015.

[66] A. Kawamoto, N. Sugano, M. Motohashi, S. Matsumoto, and K. Ito, "Relationship between salivary antioxidant capacity and phases of the menstrual cycle," Journal of Periodontal Research, vol. 47, no. 5, pp. 593-598, 2012.

[67] A. M. Khalil, K. M. Abu Khadra, A. M. Aljaberi, M. H. Gagaa, and H. S. Issa, "Assessment of oxidant/antioxidant status in saliva of cell phone users," Electromagnetic Biology and Medicine, vol. 33, no. 2, pp. 92-97, 2014.

[68] S.-C. Kim, O.-S. Kim, O.-J. Kim, Y.-J. Kim, and H.-J. Chung, "Antioxidant profile of whole saliva after scaling and root planing in periodontal disease," Journal of Periodontal and Implant Science, vol. 40, no. 4, pp. 164-171, 2010.

[69] R. Kohen, O. Tirosh, and K. Kopolovich, "The reductive capacity index of saliva obtained from donors of various ages," Experimental Gerontology, vol. 27, no. 2, pp. 161-168, 1992.

[70] E. Kolarzyk, A. Pietrzycka, M. Stępniewski, J. Łyszczarz, A. Mendyk, and A. Ostachowska-Gąsior, "Micronutrients and macronutrients and parameters of antioxidative ability in saliva of women: inhabitants of Krakow (Poland) in the course of uncomplicated singleton pregnancy," Biological Trace Element Research, vol. 114, no. 1-3, pp. 73-84, 2006.
[71] I. Kondakova, E. A. Lissi, and M. Pizarro, "Total reactive antioxidant potential in human saliva of smokers and non-smokers," Biochemistry and Molecular Biology International, vol. 47, no. 6, pp. 911-920, 1999.

[72] D. Krawczyk, J. Błaszczak, J. Borowicz, and M. MielnikBłaszczak, "Life style and risk of development of dental caries in a population of adolescents," Annals of Agricultural and Environmental Medicine, vol. 21, no. 3, pp. 576-580, 2014.

[73] D. Krawczyk, M. H. J. Sikorska-Jaroszyńska, M. MielnikBłaszczak, K. Pasternak, E. Kapeć, and M. Sztanke, "Dental caries and total antioxidant status of unstimulated mixed whole saliva in patients aged 16-23 years," Advances in Medical Sciences, vol. 57, no. 1, pp. 163-168, 2012.

[74] A. Kumar, M. C. Pant, H. S. Singh, and S. Khandelwal, "Determinants of oxidative stress and DNA damage (8-OhdG) in squamous cell carcinoma of head and neck," Indian Journal of Cancer, vol. 49, no. 3, pp. 309-315, 2012.

[75] D. Kumar, R. K. Pandey, D. Agrawal, and D. Agrawal, "An estimation and evaluation of total antioxidant capacity of saliva in children with severe early childhood caries," International Journal of Paediatric Dentistry, vol. 21, no. 6, pp. 459-464, 2011.

[76] A. Kurhańska-Flisykowska, W. Łojewski, and M. WyganowskaSwiatkowska, "Effectiveness of Emdogain in the periodontal treatment," Przeglad Lekarski, vol. 69, no. 10, pp. 1046-1048, 2012.

[77] H. Kurku, M. Kacmaz, U. Kisa, O. Dogan, and O. Caglayan, "Acute and chronic impact of smoking on salivary and serum total antioxidant capacity," Journal of Pakistan Medical Association, vol. 65, no. 2, pp. 164-169, 2015.

[78] M. F. Leite, N. F. D. Ferreira, C. D. W. M. Shitsuka et al., "Effect of topical application of fluoride gel $\mathrm{NaF} 2 \%$ on enzymatic and non-enzymatic antioxidant parameters of saliva," Archives of Oral Biology, vol. 57, no. 6, pp. 630-635, 2012.

[79] I. Lettrichová, L. Tóthová, J. Hodosy, M. Behuliak, and P. Celec, "Variability of salivary markers of oxidative stress and antioxidant status in young healthy individuals," Redox Report, 2015.

[80] S.-P. Lin, C.-Y. Li, K. Suzuki, C.-K. Chang, K.-M. Chou, and S.-H. Fang, "Green tea consumption after intense taekwondo training enhances salivary defense factors and antibacterial capacity," PLoS ONE, vol. 9, no. 1, Article ID e87580, 2014.

[81] S. Liskmann, T. Vihalemm, O. Salum, K. Zilmer, K. Fischer, and M. Zilmer, "Characterization of the antioxidant profile of human saliva in peri-implant health and disease," Clinical Oral Implants Research, vol. 18, no. 1, pp. 27-33, 2007.

[82] G. Livnat, L. Bentur, E. Kuzmisnsky, and R. M. Nagler, "Salivary profile and oxidative stress in children and adolescents with cystic fibrosis," Journal of Oral Pathology and Medicine, vol. 39, no. 1, pp. 16-21, 2010.

[83] P. Lopez-Jornet, A. Martinez-Canovas, and A. Pons-Fuster, "Salivary biomarkers of oxidative stress and quality of life in patients with oral lichen planus," Geriatrics and Gerontology International, vol. 14, no. 3, pp. 654-659, 2014.

[84] S. Mahjoub, M. Ghasempour, A. Gharage, A. Bijani, and J. Masrourroudsari, "Comparison of total antioxidant capacity in saliva of children with severe early childhood caries and cariesfree children," Caries Research, vol. 48, no. 4, pp. 271-275, 2014.

[85] V. M. Mendoza-Núñez, B. Hernández-Monjaraz, E. SantiagoOsorio, J. M. Betancourt-Rule, and M. Ruiz-Ramos, "Tai chi exercise increases SOD activity and total antioxidant status in saliva and is linked to an improvement of periodontal disease 
in the elderly," Oxidative Medicine and Cellular Longevity, vol. 2014, Article ID 603853, 6 pages, 2014.

[86] E. Meucci, C. Littarru, G. Deli, G. Luciani, L. Tazza, and G. P. Littarru, "Antioxidant status and dialysis: plasma and saliva antioxidant activity in patients with fluctuating urate levels," Free Radical Research, vol. 29, no. 5, pp. 367-376, 1998.

[87] D. Miricescu, A. Totan, B. Calenic et al., "Salivary biomarkers: relationship between oxidative stress and alveolar bone loss in chronic periodontitis," Acta Odontologica Scandinavica, vol. 72, no. 1, pp. 42-47, 2014.

[88] J. Momen-Beitollahi, A. Mansourian, F. Momen-Heravi, M. Amanlou, S. Obradov, and M. Sahebjamee, "Assessment of salivary and serum antioxidant status in patients with recurrent aphthous stomatitis," Medicina Oral, Patologia Oral y Cirugia Bucal, vol. 15, no. 4, pp. e557-e561, 2010.

[89] S. Moore, K. A. C. Calder, N. J. Miller, and C. A. Rice-Evans, "Antioxidant activity of saliva and periodontal disease," Free Radical Research, vol. 21, no. 6, pp. 417-425, 1994.

[90] S. Muchandi, H. Walimbe, M. N. Ahmed Bijle et al., "Comparative evaluation and correlation of salivary total antioxidant capacity and salivary $\mathrm{pH}$ in caries-free and severe early childhood caries children," The Journal of Contemporary Dental Practice, vol. 16, no. 3, pp. 234-237, 2015.

[91] S. Mussavira, M. Dharmalingam, and B. O. Sukumaran, "Salivary glucose and antioxidant defense markers in type II diabetes mellitus," Turkish Journal of Medical Sciences, vol. 45, no. 1, pp. 141-147, 2015.

[92] R. Nagler, L. Barness-Hadar, M. Lieba, and A. Nagler, "Salivary antioxidant capacity in graft versus host disease," Cancer Investigation, vol. 24, no. 3, pp. 269-277, 2006.

[93] R. M. Nagler, "Altered salivary profile in heavy smokers and its possible connection to oral cancer," International Journal of Biological Markers, vol. 22, no. 4, pp. 274-280, 2007.

[94] B. Narotzki, A. Z. Reznick, T. Mitki, D. Aizenbud, and Y. Levy, "Green tea drinking improves erythrocytes and saliva oxidative status in the elderly," Advances in Experimental Medicine and Biology, vol. 832, pp. 25-33, 2014.

[95] N. Novaković, S. Cakić, T. Todorović et al., "Antioxidative status of saliva before and after non-surgical periodontal treatment," Srpski Arhiv Za Celokupno Lekarstvo, vol. 141, no. 3-4, pp. 163168, 2013.

[96] N. Novakovic, T. Todorovic, M. Rakic et al., "Salivary antioxidants as periodontal biomarkers in evaluation of tissue status and treatment outcome," Journal of Periodontal Research, vol. 49, no. 1, pp. 129-136, 2014.

[97] L. A. S. Nunes, R. Brenzikofer, and D. V. Macedo, "Reference intervals for saliva analytes collected by a standardized method in a physically active population," Clinical Biochemistry, vol. 44, no. 17-18, pp. 1440-1444, 2011.

[98] V. Padmanabhan, K. Rai, A. Hegde, and S. Shetty, "Total antioxidant capacity of saliva in children with HIV," Journal of Clinical Pediatric Dentistry, vol. 34, no. 4, pp. 347-350, 2010.

[99] P. Pandey, N. V. Reddy, V. A. Rao, A. Saxena, and C. P. Chaudhary, "Estimation of salivary flow rate, $\mathrm{pH}$, buffer capacity, calcium, total protein content and total antioxidant capacity in relation to dental caries severity, age and gender," Contemporary Clinical Dentistry, vol. 6, no. 5, supplement 1, pp. S65-S71, 2015.

[100] G. Pendyala, B. Thomas, and S. Joshi, "Periodontitis, diabetes mellitus, and the lopsided redox balance: a unifying axis," Journal of Indian Society of Periodontology, vol. 17, no. 3, pp. 338344, 2013.
[101] G. Pendyala, B. Thomas, and S. R. Joshi, "Evaluation of total antioxidant capacity of saliva in type 2 diabetic patients with and without periodontal disease: a case-control study," North American Journal of Medical Sciences, vol. 5, no. 1, pp. 51-57, 2013.

[102] N. Peter, K. J. Kevin, and A. R. Shivashankara, "Effect of alcohol withdrawl on glutathione S-transferase, total antioxidant capacity and amylase in blood and saliva of alcohol-dependent males," Journal of Clinical and Diagnostic Research, vol. 7, no. 5, pp. 797-800, 2013.

[103] A. R. Prabhakar, R. Dodawad, and R. Os, "Evaluation of flow rate, $\mathrm{pH}$, buffering capacity, calcium, total protein and total antioxidant levels of saliva in caries free and caries active children-an in vivo study," International Journal of Clinical Pediatric Dentistry, vol. 2, no. 1, pp. 9-12, 2009.

[104] B. P. Preethi, D. Reshma, and P. Anand, "Evaluation of flow rate, $\mathrm{pH}$, buffering capacity, calcium, total proteins and total antioxidant capacity levels of saliva in caries free and caries active children: an in vivo study," Indian Journal of Clinical Biochemistry, vol. 25, no. 4, pp. 425-428, 2010.

[105] K. Rai, A. M. Hegde, and N. Jose, "Salivary antioxidants and oral health in children with autism," Archives of Oral Biology, vol. 57, no. 8, pp. 1116-1120, 2012.

[106] A. Rezaie, F. Ghorbani, A. Eshghtork et al., "Alterations in salivary antioxidants, nitric oxide, and transforming growth factor-beta 1 in relation to disease activity in Crohn's disease patients," Annals of the New York Academy of Sciences, vol. 1091, pp. 110-122, 2006.

[107] A. Z. Reznick, N. Shehadeh, Y. Shafir, and R. M. Nagler, "Free radicals related effects and antioxidants in saliva and serum of adolescents with Type 1 diabetes mellitus," Archives of Oral Biology, vol. 51, no. 8, pp. 640-648, 2006.

[108] D. Rodríguez de Sotillo, A. M. Velly, M. Hadley, and J. R. Fricton, "Evidence of oxidative stress in temporomandibular disorders: a pilot study," Journal of Oral Rehabilitation, vol. 38, no. 10, pp. 722-728, 2011.

[109] G. I. Ron', L. T. Shmeleva, A. V. Klein, and I. EIu, "Lipid peroxidation and the status of the basal membrane of the acinar cells in the minor salivary glands of patients with Sjögren's syndrome," Stomatologiia, no. 2, pp. 23-26, 1992.

[110] D. V. Sculley and S. C. Langley-Evans, "Periodontal disease is associated with lower antioxidant capacity in whole saliva and evidence of increased protein oxidation," Clinical Science, vol. 105, no. 2, pp. 167-172, 2003.

[111] E. Shahar, U. Attias, D. Savulescu, J. Genizin, M. Gavish, and R. Nagler, "Oxidative stress, metalloproteinase and LDH in children with intractable and non-intractable epilepsy as reflected in salivary analysis," Epilepsy Research, vol. 108, no. 1, pp. 117-124, 2014.

[112] E. Shahar, S. Pollack, E. Kedem, G. Hassoun, and R. Nagler, "Effect of HAART on salivary composition and oxidative profile in HIV-infected patients," Current HIV Research, vol. 6, no. 5, pp. 447-451, 2008.

[113] A. Shirzad, M. Pouramir, M. Seyedmajidi, N. Jenabian, A. Bijani, and M. Motallebnejad, "Salivary total antioxidant capacity and lipid peroxidation in patients with erosive oral lichen planus," Journal of Dental Research, Dental Clinics, Dental Prospects, vol. 8, no. 1, pp. 35-39, 2014.

[114] M. Shirzaiy, S. M. Ansari, J. H. Dehghan, and S. H. Ghaeni, "Total anti-oxidant capacity of saliva in chronic periodontitis patients before and after periodontal treatment," Journal of Nepal Health Research Council, vol. 12, no. 28, pp. 172-176, 2014. 
[115] H. Su, M. Gornitsky, A. M. Velly, H. Yu, M. Benarroch, and H. M. Schipper, "Salivary DNA, lipid, and protein oxidation in nonsmokers with periodontal disease," Free Radical Biology and Medicine, vol. 46, no. 7, pp. 914-921, 2009.

[116] P. Subramaniam, K. Girish Babu, and L. Mohan Das, "Assessment of salivary total antioxidant levels and oral health status in children with Down syndrome," Special Care in Dentistry, vol. 34, no. 4, pp. 193-200, 2014.

[117] P. Subramaniam, L. Mohan Das, and K. L. Babu, "Assessment of salivary total antioxidant levels and oral health status in children with cerebral palsy," Journal of Clinical Pediatric Dentistry, vol. 38, no. 3, pp. 235-239, 2014.

[118] H. Suma, K. Prabhu, R. P. Shenoy, R. Annaswamy, S. Rao, and A. Rao, "Estimation of salivary protein thiols and total antioxidant power of saliva in brain tumor patients," Journal of Cancer Research and Therapeutics, vol. 6, no. 3, pp. 278-281, 2010.

[119] A. Surdacka, E. Ciężka, M. Pioruńska-Stolzmann et al., "Relation of salivary antioxidant status and cytokine levels to clinical parameters of oral health in pregnant women with diabetes," Archives of Oral Biology, vol. 56, no. 5, pp. 428-436, 2011.

[120] H. S. Tavakol, R. Akram, S. Azam, and Z. Nahid, "Protective effects of green tea on antioxidative biomarkers in chemical laboratory workers," Toxicology and Industrial Health, vol. 31, no. 9, pp. 862-867, 2015.

[121] A. Totan, D. Miricescu, I. Parlatescu, M. Mohora, and M. Greabu, "Possible salivary and serum biomarkers for oral lichen planus," Biotechnic \& Histochemistry, vol. 90, no. 7, pp. 552-558, 2015.

[122] L. Tóthová, V. Celecová, and P. Celec, "Salivary markers of oxidative stress and their relation to periodontal and dental status in children," Disease Markers, vol. 34, no. 1, pp. 9-15, 2013.

[123] L. Tóthová, J. Hodosy, I. Mucska, and P. Celec, "Salivary markers of oxidative stress in patients with obstructive sleep apnea treated with continuous positive airway pressure," Sleep and Breathing, vol. 18, no. 3, pp. 563-570, 2014.

[124] Ö. Tulunoglu, S. Demirtas, and I. Tulunoglu, "Total antioxidant levels of saliva in children related to caries, age, and gender," International Journal of Paediatric Dentistry, vol. 16, no. 3, pp. 186-191, 2006.

[125] J. Uberos, J. A. Alarcón, M. A. Peñalver et al., "Influence of the antioxidant content of saliva on dental caries in an at-risk community," British Dental Journal, vol. 205, no. 2, article E5, 2008.

[126] Y. Ullmann, Y. Klein, D. Savulescu et al., "Salivary monitoring related to major surgery," European Journal of Clinical Investigation, vol. 40, no. 12, pp. 1074-1080, 2010.

[127] E. M. Varoni, S. Vitalini, D. Contino et al., "Effects of red wine intake on human salivary antiradical capacity and total polyphenol content," Food and Chemical Toxicology, vol. 58, pp. 289-294, 2013.

[128] B. Vlková, P. Stanko, G. Minárik et al., "Salivary markers of oxidative stress in patients with oral premalignant lesions," Archives of Oral Biology, vol. 57, no. 12, pp. 1651-1656, 2012.

[129] C. Vors, J. Drai, L. Gabert et al., "Salivary composition in obese vs normal-weight subjects: towards a role in postprandial lipid metabolism?" International Journal of Obesity, vol. 39, no. 9, pp. 1425-1428, 2015.

[130] M. Wnuk, A. Myszka, A. Lewinska, I. Tokarz, K. Solarska, and G. Bartosz, "Helicobacter pylori cagA gene polymorphism affects the total antioxidant capacity of human saliva," Helicobacter, vol. 15, no. 1, pp. 53-57, 2010.
[131] P. S. Yang, W. C. Huang, S. Y. Chen et al., "Scaling-stimulated salivary antioxidant changes and oral-health behavior in an evaluation of periodontal treatment outcomes," The Scientific World Journal, vol. 2014, Article ID 814671, 8 pages, 2014.

[132] M. Yigla, Y. Berkovich, and R. M. Nagler, "Oxidative stress indices in COPD-broncho-alveolar lavage and salivary analysis," Archives of Oral Biology, vol. 52, no. 1, pp. 36-43, 2007.

[133] G. Yousefzadeh, B. Larijani, A. Mohammadirad et al., "Determination of oxidative stress status and concentration of TGF- $\beta 1$ in the blood and saliva of osteoporotic subjects," Annals of the New York Academy of Sciences, vol. 1091, pp. 142-150, 2006.

[134] H. Youssef, C. Groussard, G. Machefer et al., "Comparison of total antioxidant capacity of salivary, capillary and venous samplings: interest of the salivary total antioxidant capacity on triathletes during training season," Journal of Sports Medicine and Physical Fitness, vol. 48, no. 4, pp. 522-529, 2008.

[135] A. Zalewska, M. Knaś, E. Gińdzieńska-Sieśkiewicz et al., "Salivary antioxidants in patients with systemic sclerosis," Journal of Oral Pathology and Medicine, vol. 43, no. 1, pp. 61-68, 2014.

[136] B. Zappacosta, S. Persichilli, P. De Sole, A. Mordente, and B. Giardina, "Effect of smoking one cigarette on antioxidant metabolites in the saliva of healthy smokers," Archives of Oral Biology, vol. 44, no. 6, pp. 485-488, 1999.

[137] A. Zare Javid, C. J. Seal, P. Heasman, and P. J. Moynihan, "Impact of a customised dietary intervention on antioxidant status, dietary intakes and periodontal indices in patients with adult periodontitis," Journal of Human Nutrition and Dietetics, vol. 27, no. 6, pp. 523-532, 2014.

[138] A. Ziobro and G. Bartosz, "A comparison of the total antioxidant capacity of some human body fluid," Cellular and Molecular Biology Letters, vol. 8, no. 2, pp. 415-419, 2003.

[139] S. Abusoglu, H. T. Celik, E. Tutkun et al., "8-Hydroxydeoxyguanosine as a useful marker for determining the severity of trichloroethylene exposure," Archives of Environmental and Occupational Health, vol. 69, no. 3, pp. 180-186, 2014.

[140] H. Benkhai, S. Lemanski, H. Below et al., "Can physical stress be measured in urine using the parameter antioxidative potential?" GMS Krankenhaushygiene Interdisziplinär, vol. 5, no. 2, Article ID Doc03, 2010.

[141] I. F. F. Benzie, Y. T. Szeto, J. J. Strain, and B. Tomlinson, "Consumption of green tea causes rapid increase in plasma antioxidant power in humans," Nutrition and Cancer, vol. 34, no. 1, pp. 83-87, 1999.

[142] G. Boudouris, I. I. Verginadis, Y. V. Simos et al., "Oxidative stress in patients treated with continuous ambulatory peritoneal dialysis (CAPD) and the significant role of vitamin C and e supplementation," International Urology and Nephrology, vol. 45, no. 4, pp. 1137-1144, 2013.

[143] R. Bravo, S. Matito, J. Cubero et al., "Tryptophan-enriched cereal intake improves nocturnal sleep, melatonin, serotonin, and total antioxidant capacity levels and mood in elderly humans," Age, vol. 35, no. 4, pp. 1277-1285, 2013.

[144] H. Buyukhatipoglu, Y. Sezen, A. Yildiz et al., "N-acetylcysteine fails to prevent renal dysfunction and oxidative stress after noniodine contrast media administration during percutaneous coronary interventions," Polskie Archiwum Medycyny Wewnętrznej, vol. 120, no. 10, pp. 383-389, 2010.

[145] C. Campos, R. Guzmán, E. López-Fernández, and Á. Casado, "Urinary biomarkers of oxidative/nitrosative stress in healthy smokers,' Inhalation Toxicology, vol. 23, no. 3, pp. 148-156, 2011.

[146] C. Campos, R. Guzmán, E. López-Fernández, and Á. Casado, "Urinary uric acid and antioxidant capacity in children and 
adults with Down syndrome," Clinical Biochemistry, vol. 43, no. 3, pp. 228-233, 2010.

[147] G. Cao, R. M. Russell, N. Lischner, and R. L. Prior, "Serum antioxidant capacity is increased by consumption of strawberries, spinach, red wine or vitamin C in elderly women," Journal of Nutrition, vol. 128, no. 12, pp. 2383-2390, 1998.

[148] J.-W. Chien, L.-Y. Wang, Y.-S. Cheng, Y.-G. Tsai, and C.-S. Liu, "Urinary 8-hydroxy-2'-deoxyguanosine (8-oxodG) level can predict acute renal damage in young children with urinary tract infection," Biomarkers, vol. 19, no. 4, pp. 326-331, 2014.

[149] H. Ciftci, A. Verit, E. Yeni, and M. Savas, "Decreased oxidative stress index of urine in patients with urinary tract infection," Urologia Internationalis, vol. 81, no. 3, pp. 312-315, 2008.

[150] L. P. M. Damodaran and G. Arumugam, "Urinary oxidative stress markers in children with autism," Redox Report, vol. 16, no. 5, pp. 216-222, 2011.

[151] M. Dos Santos Mello, G. S. Ribas, C. A. Y. Wayhs et al., "Increased oxidative stress in patients with 3-hydroxy-3methylglutaric aciduria," Molecular and Cellular Biochemistry, vol. 402, no. 1-2, pp. 149-155, 2015.

[152] S.-Y. Eom, D.-H. Yim, S. I. Moon et al., "Polycyclic aromatic hydrocarbon-induced oxidative stress, antioxidant capacity, and the risk of lung cancer: a pilot nested case-control study," Anticancer Research, vol. 33, no. 8, pp. 3089-3097, 2013.

[153] M. Garrido, S. D. Paredes, J. Cubero et al., "Jerte valley cherry-enriched diets improve nocturnal rest and increase 6-sulfatoxymelatonin and total antioxidant capacity in the urine of middle-aged and elderly humans," The Journals of Gerontology Series A: Biological Sciences and Medical Sciences, vol. 65, no. 9, pp. 909-914, 2010.

[154] N. Göknar, F. Oktem, E. Ari, A. D. Demir, and E. Torun, "Is oxidative stress related to childhood urolithiasis?" Pediatric Nephrology, vol. 29, no. 8, pp. 1381-1386, 2014.

[155] D. González-Flores, E. Gamero, M. Garrido et al., "Urinary 6sulfatoxymelatonin and total antioxidant capacity increase after the intake of a grape juice cv. Tempranillo stabilized with HHP," Food and Function, vol. 3, no. 1, pp. 34-39, 2012.

[156] G. Guerreiro, C. P. Mescka, A. Sitta et al., "Urinary biomarkers of oxidative damage in Maple syrup urine disease: the L-carnitine role," International Journal of Developmental Neuroscience, vol. 42, pp. 10-14, 2015.

[157] N. M. A. Hassimotto, M. D. S. Pinto, and F. M. Lajolo, "Antioxidant status in humans after consumption of blackberry (Rubus fruticosus L.) juices with and without defatted milk," Journal of Agricultural and Food Chemistry, vol. 56, no. 24, pp. 11727-11733, 2008.

[158] N. K. Hatipoğlu, O. Evliyaoğlu, B. Işik et al., "Antioxidant signal and kidney injury molecule-1 levels in shockwave lithotripsy induced kidney injury," Journal of Endourology, vol. 28, no. 2, pp. 224-228, 2014.

[159] D. Helbig, A. Wagner, R. Schubert, and G. Jahreis, "Tocopherol isomer pattern in serum and stool of human following consumption of black currant seed press residue administered in whole grain bread," Clinical Nutrition, vol. 28, no. 6, pp. 662$667,2009$.

[160] C. Hudthagosol, E. Haddad, and R. Jongsuwat, "Antioxidant activity comparison of walnuts and fatty fish," Journal of the Medical Association of Thailand, vol. 95, supplement 6, pp. S179S188, 2012.

[161] K. Jacob, M. J. Periago, V. Böhm, and G. R. Berruezo, "Influence of lycopene and vitamin $\mathrm{C}$ from tomato juice on biomarkers of oxidative stress and inflammation," British Journal of Nutrition, vol. 99, no. 1, pp. 137-146, 2008.

[162] B. Kirschbaum, "Total urine antioxidant capacity," Clinica Chimica Acta, vol. 305, no. 1-2, pp. 167-173, 2001.

[163] P. J. Mc Guire, A. Parikh, and G. A. Diaz, "Profiling of oxidative stress in patients with inborn errors of metabolism," Molecular Genetics and Metabolism, vol. 98, no. 1-2, pp. 173-180, 2009.

[164] C. Miglio, I. Peluso, A. Raguzzini et al., "Fruit juice drinks prevent endogenous antioxidant response to high-fat meal ingestion," British Journal of Nutrition, vol. 111, no. 2, pp. 294300, 2014.

[165] M. Patchsung, C. Boonla, P. Amnattrakul, T. Dissayabutra, A. Mutirangura, and P. Tosukhowong, "Long interspersed nuclear element-1 hypomethylation and oxidative stress: correlation and bladder cancer diagnostic potential," PLoS ONE, vol. 7, no. 5, Article ID e37009, 2012.

[166] B. Pfundstein, R. Haubner, G. Würtele, N. Gehres, C. M. Ulrich, and R. W. Owen, "Pilot walnut intervention study of urolithin bioavailability in human volunteers," Journal of Agricultural and Food Chemistry, vol. 62, no. 42, pp. 10264-10273, 2014.

[167] A. Ranjbar, V. Rashedi, and M. Rezaei, "Comparison of urinary oxidative biomarkers in Iranian children with autism," Research in Developmental Disabilities, vol. 35, no. 11, pp. 2751-2755, 2014.

[168] R. Revuelta-Iniesta and E. A. S. Al-Dujaili, "Consumption of green coffee reduces blood pressure and body composition by influencing $11 \beta$-HSD1 enzyme activity in healthy individuals: a pilot crossover study using green and black coffee," BioMed Research International, vol. 2014, Article ID 482704, 9 pages, 2014.

[169] G. S. Ribas, G. B. Biancini, C. Mescka et al., "Oxidative stress parameters in urine from patients with disorders of propionate metabolism: a beneficial effect of L:-carnitine supplementation," Cellular and Molecular Neurobiology, vol. 32, no. 1, pp. 77-82, 2012.

[170] E. Roura, M. P. Almajano, M. L. M. Bilbao, C. Andrés-Lacueva, R. Estruch, and R. M. Lamuela-Raventós, "Human urine: epicatechin metabolites and antioxidant activity after cocoa beverage intake," Free Radical Research, vol. 41, no. 8, pp. 943949, 2007.

[171] M. C. Schmidt, E. W. Askew, D. E. Roberts, R. L. Prior, W. Y. Ensign Jr., and R. E. Hesslink Jr., "Oxidative stress in humans training in a cold, moderate altitude environment and their response to a phytochemical antioxidant supplement," Wilderness and Environmental Medicine, vol. 13, no. 2, pp. 94$105,2002$.

[172] K. Shermatov, D. Zeyrek, F. Yildirim, M. Kilic, N. Cebi, and A. Kocyigit, "DNA damage in children exposed to secondhand cigarette smoke and its association with oxidative stress," Indian Pediatrics, vol. 49, no. 12, pp. 958-962, 2012.

[173] D. A. Shoskes, A. R. Shahed, S. Kim, H. A. Gritsch, G. Danovitch, and A. Wilkinson, "Oxidant stress and antioxidant capacity in urine of renal transplant recipients predict early graft function," Transplantation Proceedings, vol. 33, no. 1-2, p. 984, 2001.

[174] D. A. Shoskes, R. Webster, and A. Shahed, "Oxidant stress in cadaveric and living kidney donors as markers of renal injury: utility of total antioxidant capacity and isoprostane levels in urine," Transplantation Proceedings, vol. 32, no. 4, pp. 804-805, 2000.

[175] K. Silliman, J. Parry, L. L. Kirk, and R. L. Prior, "Pycnogenol does not impact the antioxidant or vitamin $\mathrm{C}$ status of healthy 
young adults," Journal of the American Dietetic Association, vol. 103, no. 1, pp. 67-72, 2003.

[176] R. J. Stewart, E. W. Askew, C. M. McDonald et al., "Antioxidant status of young children: response to an antioxidant supplement," Journal of the American Dietetic Association, vol. 102, no. 11, pp. 1652-1657, 2002.

[177] S. Wachtel-Galor, Y.-T. Szeto, B. Tomlinson, and I. F. F. Benzie, "Ganoderma lucidum ('Lingzhi'); acute and short-term biomarker response to supplementation," International Journal of Food Sciences and Nutrition, vol. 55, no. 1, pp. 75-83, 2004.

[178] S. Wachtel-Galor, B. Tomlinson, and I. F. F. Benzie, "Ganoderma lucidum ('Lingzhi'), a Chinese medicinal mushroom: biomarker responses in a controlled human supplementation study," British Journal of Nutrition, vol. 91, no. 2, pp. 263-269, 2004.

[179] E. Yilmaz, A. Haciislamoglu, U. Kisa, O. Dogan, E. Yuvanc, and E. Batislam, "Ways in which SWL affects oxidant/antioxidant balance," Urological Research, vol. 41, no. 2, pp. 137-141, 2013.

[180] Z. Liu, Y. Liu, Y. Song, X. Zhang, S. Wang, and Z. Wang, "Systemic oxidative stress biomarkers in chronic periodontitis: a meta-analysis," Disease Markers, vol. 2014, Article ID 931083, 10 pages, 2014.

[181] R. S. Bhangoo, I. E. Hall, P. P. Reese, and C. R. Parikh, "Deceased-donor kidney perfusate and urine biomarkers for kidney allograft outcomes: a systematic review," Nephrology Dialysis Transplantation, vol. 27, no. 8, pp. 3305-3314, 2012.

[182] F. Bonomini, L. F. Rodella, and R. Rezzani, "Metabolic syndrome, aging and involvement of oxidative stress," Aging and Disease, vol. 6, no. 2, pp. 109-120, 2015.

[183] W. Y. Tae, C. S. Ki, S. S. Hun et al., "Relationship between serum uric acid concentration and insulin resistance and metabolic syndrome," Circulation Journal, vol. 69, no. 8, pp. 928-933, 2005.

[184] B. E. K. Klein, R. Klein, and K. E. Lee, "Components of the metabolic syndrome and risk of cardiovascular disease and diabetes in Beaver Dam," Diabetes Care, vol. 25, no. 10, pp. 17901794, 2002.

[185] R. Kawamoto, H. Tomita, Y. Oka, and N. Ohtsuka, "Relationship between serum uric acid concentration, metabolic syndrome and carotid atherosclerosis," Internal Medicine, vol. 45, no. 9, pp. 605-614, 2006.

[186] M. Serafini, C. Miglio, I. Peluso, and T. Petrosino, "Modulation of plasma non enzimatic antioxidant capacity (NEAC) by plant foods: the role of polyphenols," Current Topics in Medicinal Chemistry, vol. 11, no. 14, pp. 1821-1846, 2011.

[187] F. Veglia, G. Cighetti, M. De Franceschi et al., "Age- and gender-related oxidative status determined in healthy subjects by means of OXY-SCORE, a potential new comprehensive index," Biomarkers, vol. 11, no. 6, pp. 562-573, 2006.

[188] N. Kamodyová and P. Celec, "Salivary markers of oxidative stress and Salivette collection systems," Clinical Chemistry and Laboratory Medicine, vol. 49, no. 11, pp. 1887-1890, 2011.

[189] E. Neyraud, O. Palicki, C. Schwartz, S. Nicklaus, and G. Feron, "Variability of human saliva composition: possible relationships with fat perception and liking," Archives of Oral Biology, vol. 57, no. 5, pp. 556-566, 2012.

[190] R. M. Nagler, I. Klein, N. Zarzhevsky, N. Drigues, and A. Z. Reznick, "Characterization of the differentiated antioxidant profile of human saliva," Free Radical Biology and Medicine, vol. 32, no. 3, pp. 268-277, 2002.

[191] I. R. Gunn, "Biological variation of serum and urine creatinine and creatinine clearance," Annals of Clinical Biochemistry, vol. 26, part 3, pp. 302-303, 1989.
[192] A. Ghiselli, M. Serafini, G. Maiani, E. Azzini, and A. Ferro-Luzzi, "A fluorescence-based method for measuring total plasma antioxidant capability," Free Radical Biology and Medicine, vol. 18, no. 1, pp. 29-36, 1995.

[193] I. F. F. Benzie and J. J. Strain, "The ferric reducing ability of plasma (FRAP) as a measure of 'antioxidant power': the FRAP assay," Analytical Biochemistry, vol. 239, no. 1, pp. 70-76, 1996.

[194] E. Lissi, M. Salim-Hanna, C. Pascual, and M. D. del Castillo, "Evaluation of total antioxidant potential (TRAP) and total antioxidant reactivity from luminol-enhanced chemiluminescence measurements," Free Radical Biology and Medicine, vol. 18, no. 2, pp. 153-158, 1995.

[195] B. T. Emmerson, “The management of gout," The New England Journal of Medicine, vol. 334, no. 7, pp. 445-451, 1996.

[196] F. H. Messerli, E. D. Frohlich, G. R. Dreslinski, D. H. Suarez, and G. G. Aristimuno, "Serum uric acid in essential hypertension: an indicator of renal vascular involvement," Annals of Internal Medicine, vol. 93, no. 6, pp. 817-821, 1980.

[197] A. Quiñones Galvan, A. Natali, S. Baldi et al., "Effect of insulin on uric acid excretion in humans," American Journal of Physiology, vol. 268, pp. E1-E5, 1995.

[198] D. Duplancic, L. Kukoc-Modun, D. Modun, and N. Radic, "Simple and rapid method for the determination of uric acidindependent antioxidant capacity," Molecules, vol. 16, no. 8, pp. 7058-7067, 2011.

[199] N. Malliaraki, D. Mpliamplias, M. Kampa, K. Perakis, A. N. Margioris, and E. Castanas, "Total and corrected antioxidant capacity in hemodialyzed patients," BMC Nephrology, vol. 4, article 4, 2003.

[200] R. Bentley and A. Neuberger, "The mechanism of the action of uricase," The Biochemical Journal, vol. 52, no. 4, pp. 694-699, 1952. 


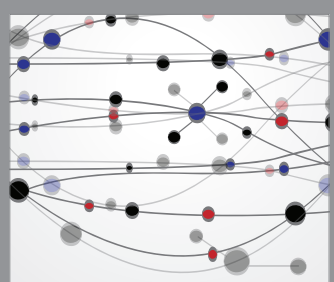

The Scientific World Journal
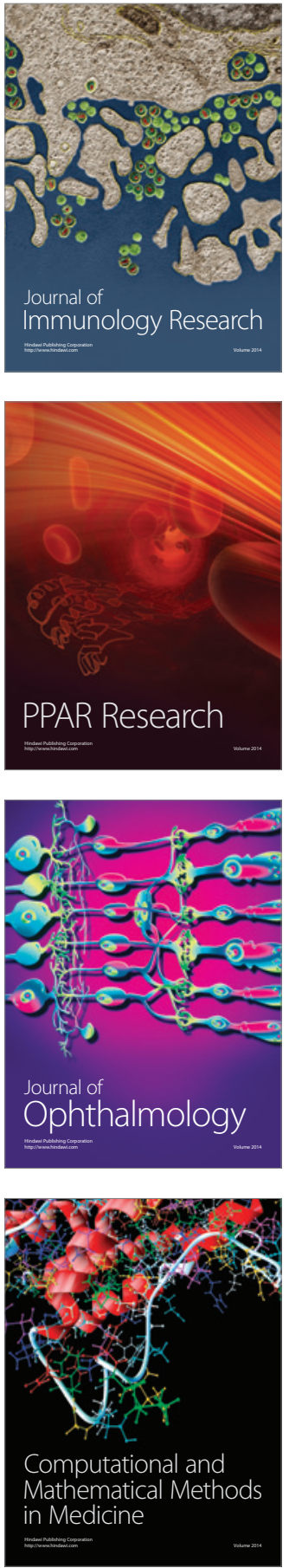

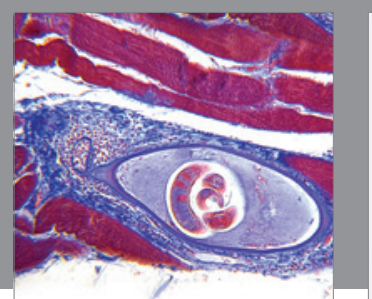

Gastroenterology Research and Practice

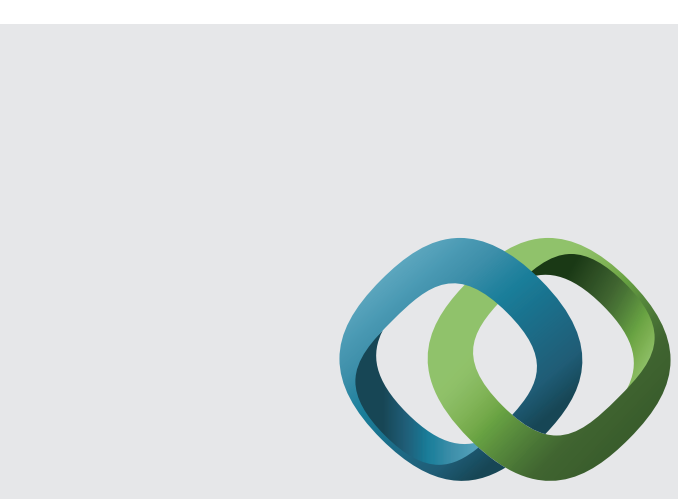

\section{Hindawi}

Submit your manuscripts at

http://www.hindawi.com
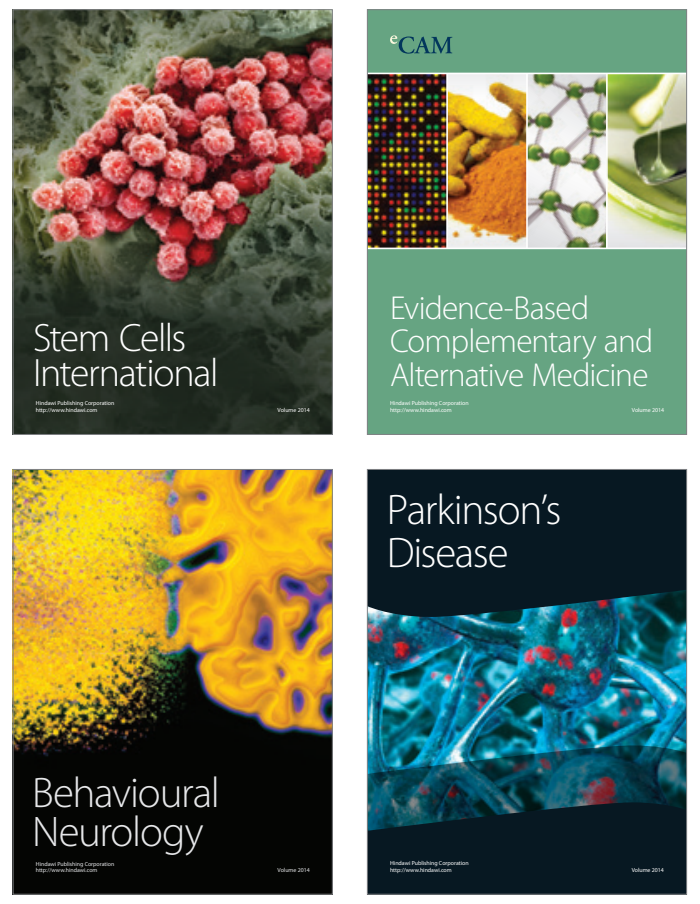
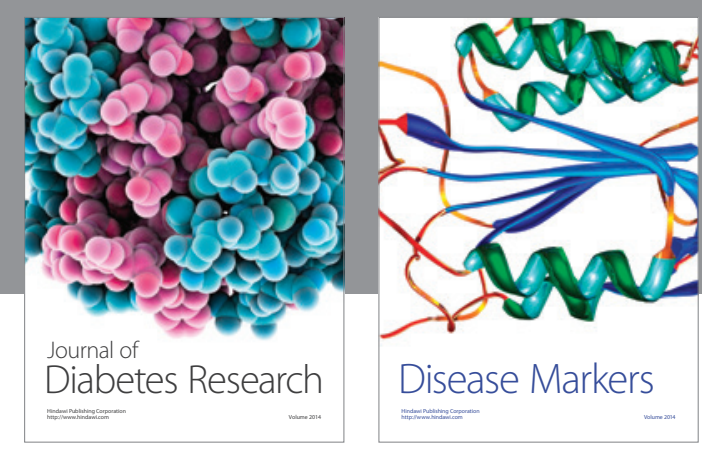

Disease Markers
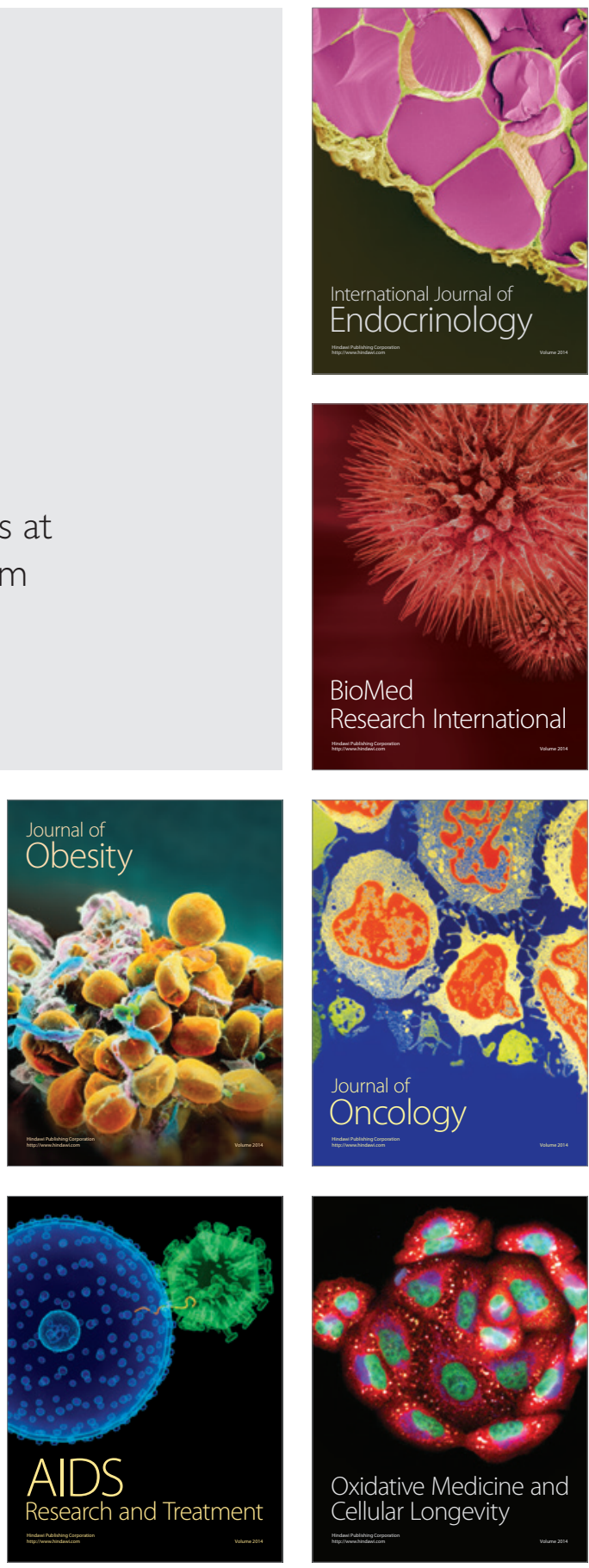